Articles

\title{
Adjectives in Thai: Implications for a functionalist typology of word classes
}

MARK POST

\begin{abstract}
Tai languages are often described as "lacking" a major lexical class "adjectives"; accordingly, they and other area languages are frequently cited as evidence against adjectival universality. This article brings the putative lack under examination, arguing that a more complete distributional analysis reveals a pattern: overlap is highest among semantically peripheral adjectives and verbs and in constructions prototypically associated to both classes crosslinguistically, and lowest among semantically core adjectives and verbs and in constructions prototypically associated to only one or the other class. Rather than "lacking" adjectives, data from Thai thus in fact support functionaltypological characterizations of adjectival universality such as those of Givon (1984), Croft (2001), and Dixon (2004). Finally, while data from Thai would fail to falsify an adaptation of Enfield's (2004) Lao lexical class-taxonomy (in which adjectives are treated as a verbal subclass) on its own terms, this article argues that in absence of both universally-applicable criteria for the evaluation of categorial taxonomies crosslinguistically and evidence for the cognitive reality of categorial taxonomies so stipulated, even this more limited sense of a "lack" of adjectives in Thai is less radical a challenge to adjectival universality than has sometimes been supposed.
\end{abstract}

Keywords: adjectives, categorization, derivation, lexicon, syntax, Tai languages, Thai, word classes

\section{Introduction}

In literature dealing with the mainly isolating, analytical languages of Greater Mainland South-East Asia (GMSEA), it is common to find statements to the effect that particular GMSEA languages "lack" adjectives, or that notional ad- 
jectives in particular GMSEA languages "are actually" (a subclass of) verbs. ${ }^{1}$ Such languages are in turn regularly cited as evidence against the universal instantiation of a category "adjective", such as would be found in most generative theories (e.g., Baker 2003, and many references therein) as well as in more functional- and/or typologically-oriented theories concerning the (universal) crosslinguistic representation of lexical categories such as those of Givón (1984), Croft (1991, 2001, 2005), and Dixon (2004). Following the seminal study of Dixon (1977) - later substantially revised and reworked in Dixon 2004 - Bhat \& Pustet (2000: 757-758) cite a number of GMSEA languages which "do not have any distinct category of adjectives as such [...] merging them with verbs". Evans (2000: 714) states the typological consequences of these facts as he views them quite plainly: "adjectives are by no means a universal word class". Claims regarding the cognitive implications of a "lack of adjectives" in GMSEA languages can take on even more radical proportions, with at least one well-known paper entertaining the possibility that "the lack of [a] distinct category adjective in Thai" may be somehow "related to Thai thought" (Prasithrathsint 2000: 268). ${ }^{2}$

The present article will take a somewhat different view. In it, we will have several objectives: the first is to draw together a more comprehensive description of the relevant set of phenomena in Modern Standard Thai (henceforth "Thai") than may be found in most other works which address the topic directly. In the process, we will take into account the (semantically-based) internal structure of the Thai adjective class, as well as the behaviour of semantically comparable members of other word classes. On the basis of this more comprehensive description, the categorial status of Thai adjectives will be re-assessed, and compared with the similar but non-identical facts of Lao (as described in Enfield 2004, 2007). Following this re-assessment, we will also re-visit the question of whether Thai can truly be said to "not have" adjectives, in the same sense in which, for example, English "doesn't have" the category "sortal classifier"; or, if not, we will re-consider exactly what this putative "lack" of adjectives in Thai (or in other GMSEA languages) can mean for typology and general linguistic theory.

1. Commonly-cited examples include Vietnamese (L. Thompson 1991), Chinese (McCawley 1992), Lahu (Matisoff 1973), Lao (Enfield 2004), and Thai (Prasithrathsint 2000), among others.

2. The same author goes on to speculate that an alleged lack of descriptive content in Thai literature (of a character's appearance, personality, etc.) by comparison with Western literature "may be inferred" to result from the "lack of a category of adjective in Thai" (Prasithrathsint 2000: 269). 


\section{The nature and identification of adjective classes}

Typological investigations of the properties of adjective classes across languages have yielded a number of important and fairly stable generalizations. Primarily following Dixon $(1977,2004)$, adjective classes are nowadays routinely identified as prototypically containing words denoting property concepts. From a more general semantic perspective, Croft (2001: Section 2.4.2), following Langacker 1987 and Croft 1991, distinguishes the relative gradability of adjectival property concepts from the relatively non-gradable concepts prototypically associated with noun and verb classes (i.e., an entity can be construed as "more or less large" more readily than it may be construed as "more or less a stone" or "more or less breathing"). Fundamentally, the semantic property of gradability would seem to lend adjectives an aptness for degree modification (more/less, a lot/little, the most/least), for lexicalization as points on a property scale (tiny, small, big, huge, ...), as well as for comparison in terms of the relative degree of properties exhibited by two referents; Jespersen (1924) distinguished adjectives in similarly semantic terms as dealing with "one property at a time".

From a narrower semantic perspective, Dixon $(1977,2004)$ subdivides adjective classes into CORE types DIMENSION (big, small ...), AGE (new, old ...), VALUE ( good, bad ...), and COLOUR (black, white ...), and PERIPHERAL types PHYSICAL PROPERTY (hard, soft ...), HUMAN PROPENSITY (happy, sad ...), and SPEED (fast, slow ...). Especially large adjective classes may include terms of DIFFICULTY (easy, difficult), SIMILARITY (same, different), QUALIFICATION (true, false), QUANTIFICATION (many, few), POSITION (high, low), and CARDINAL and/or ORDINAL NUMBERS (first, second). ${ }^{3}$

Functionally, adjectives prototypically attribute features to a referent, whether for the purpose of enhancing an active discourse-reference or introducing a new discourse-reference under restrictive modification (S. Thompson 1991). Syntactically, adjectival attributive functions may be realized via predication - whether as an intransitive predicate or as copula complement - or via nominal modification, according to discourse function. Opinions have differed as to whether one or the other of the predicative or nominal-modifying functions should be construed as primary or prototypical in a typological sense,

3. The division of adjectives into "core" and "peripheral" types in Dixon's sense is fundamentally a TYPOLOGICALLY-motivated move, reflecting the observed relative tendencies for terms from the listed fields to occur in the adjective classes of languages which clearly exhibit them. The implicit claim is that the observed typological distribution is in turn likely to be in some sense SEMANTICALLY-motivated. In her crosslinguistic study of copulas Pustet (2003) argues that the distinctions between prototypical (or core) and less prototypical (or peripheral) types of adjectives, verbs, and nouns are defined by various combinations of three semantic parameters of valence, transience, and dynamicity. 
with Evans (2000: 714), Bhat \& Pustet (2000: 757), Hengeveld (1992: 58), Croft (2001: Section 2), and Baker (2003: 191) asserting the modifying context to be more central or prototypical, and Schachter (1985) and Dixon (2004) dividing syntactic functions of adjectives essentially equally among predication and modification. ${ }^{4}$ For present purposes, it will not be necessary to resolve this disagreement; suffice it to say that all analysts agree that both predicative and nominal-modifying environments are potentially relevant to the recognition and definition of adjective classes, and to the explanation of their behaviour and distribution.

Finally, although this concept seems perhaps to be less clearly worked-out, adjectives are often viewed as inherently mono-relational, in the semantic sense that their denotation may be viewed as incomplete without simultaneous construal of some entity or set which exhibits the stated property (e.g., a man who is tall), and in the syntactic sense that they either project (as predicate), cooccur with (as copula complement), or depend on (as modifier) one and only one referring expression. This characterization is explicit in Croft (2001: Section 2) and implicit in Dixon (2004). ${ }^{5}$

To summarize the above, adjectives are generally viewed as a class of lexemes which prototypically denote semantically gradable, mono-relational property concepts. They function primarily to attribute features of a referent via predication or modification, and secondarily occur in constructions which modify the degree of, or establish a comparison of, properties attributed to one or more referents.

\section{Property terms in Thai: A preliminary assessment}

Terms denoting property concepts in Thai are primarily divisible into verblike and nounlike forms, the vast majority being of the first type ${ }^{6}$ Verblike property concepts in Thai include terms from all of the core and peripheral semantic fields identified by Dixon $(1977,2004)$, as well as a few from Dixon's extraperipheral fields (excluding NUMBERs); examples are dii 'good', $j \hat{\varepsilon} \varepsilon$ 'bad', róon 'hot', and năaw 'cold'. Nounlike property concepts in Thai mainly correspond to the fields of PHYSICAL PROPERTY, HUMAN PROPENSITY, and COLOUR; examples are thammachâat 'natural(ness)', sùantua 'private/privacy', sanı̌m

4. The Schachter-Dixon position is implicitly supported by S. Thompson's (1991) data, although in terms of discourse-frequency rather than prototypicality in any typological sense.

5. An anonymous referee points out that adjectival mono-relationality may not be absolute, as bi-relational terms exist in various languages which may qualify as basic adjectives (e.g., English worth). In terms of an overall typology, however, such cases would almost certainly be viewed as non-prototypical.

6. Without yet making a claim on the lexical class-affiliations of such terms, we can note an implicit conceptual correspondence with Stassen's (1997) identification of "verby" and "nouny" adjectives. 
'rust(y)', and (sii) sôm '(colour of) orange(s)'. Previous studies treating property terms in Tai languages ${ }^{7}$ have primarily focused on the far more numerous and semantically diverse verblike forms, although Iwasaki \& Ingkaphirom (2005) also discuss the nounlike forms in some detail. In terms of basic distribution, verblike property concepts - like all active and stative verbs in Thai - occur as intransitive predicates $(1 \mathrm{a}, \mathrm{c})$, and do not usually occur as copula complement (1b, d). Conversely, nounlike property concepts behave more like concrete and abstract nouns in occurring as complement of an attributive copula or other, similarly predicative functor $(1 \mathrm{e}, \mathrm{g})$. In most though not all cases, they may not occur as intransitive predicate $(1 \mathrm{f}, \mathrm{h})$.
a. khon ní dəən.
CLF:PERSON PRX walk
'This person walks.' (active verb, intransitive predicate)
b. *khon nii pen dəən.
CLF:PERSON PRX ACOP walk
c. khon nii dii.
CLF:PERSON PRX gOod
'This person is good.' (verblike property term, intransitive pred- icate)
CLF:PERSON PRX ACOP gOOd
e. khan níi pen sanim
CLF:VEHICLE PRX ACOP $\operatorname{rust}(\mathrm{y})$
d. *khon nii pen dii.
'This vehicle is rusty.' (nounlike property term, copula comple- ment)
f. *l?khan nii sanim.
CLF:VEHICLE PRX rust(y)
g. khon níi pen phrá?
CLF:PERSON PRX ACOP monk
'This person is a monk.' (concrete noun, copula complement)
h. *khon níi phrá?.
CLF:PERSON PRX mOnk

Most of the arguments which have been adduced as evidence for the basic "verbal" class-affiliation of verblike property concepts in Thai either follow directly from or are otherwise closely associated to this basic behavioural difference in the context of predication. For example, the same basic set of similarities and differences are maintained in the context of relative clause formation in thîl 'REL' (2a-h); this is because relative clause formation in Thai is

7. See Prasithrathsint 2000 for a good review of pre-2000 studies. 


\section{Mark Post}

based on the predication construction, as might be anticipated (see also Section $4.2)$.
a. khon thîi dəən
CLF:PERSON REL walk
'the person who walks' (active verb, intransitive predicate)
b. *khon thîi pen dəə⿳亠二口丿
CLF:PERSON REL ACOP walk
c. khon thîi dii
CLF:PERSON REL goOd
'the person who is good' (verblike property term, intransitive predicate)
d. *khon thîi pen dii
CLF:PERSON REL ACOP gOOd
e. khon thîi pen sanı̌m
CLF:VEHICLE REL ACOP rust(y)
'the vehicle that is rusty' (nounlike property term, copula com- plement)
f. */?khan thîi sanǐm
CLF:VEHICLE REL rust(y)
g. khon thîi pen phrá?
CLF:PERSON REL ACOP mOnk
'the person who is a monk' (concrete noun, copula complement)
h. *khon thîi phrá?
CLF:PERSON REL monk

Similarly, verblike property terms take direct verbal predicate negation in mâj 'NEG' whereas nounlike property terms, like nouns, again usually require support of a copula or other predicative functor. And, certain predicate operators (such as Perfective particle and/or post-head functor adverb lé $\varepsilon w$ 'already') directly modify and have scope over verbs and verblike property concepts but logically modify and have scope over an obligatory copula or other predicative functor when following a noun or nounlike property concept. ${ }^{8}$ In sum, the basic differences in the treatment of verbs and nouns (and, in turn, in the treatment of verblike and nounlike property terms) in the predication construction are also observed in several areas of the grammar in which the basic formal properties of the predication construction are maintained.

However, there are other areas of the grammar - many of which are not immediately relatable to the function of predication and do not, therefore, draw

\footnotetext{
8. Examples are not provided here in the interest of space, but may be easily found in the very clear presentations of Prasithrathsint (2000) for Thai and Enfield (2004) for Lao.
} 
directly upon the formal properties of the predication construction - in which verblike property terms are in fact quite clearly distinguishable from terms of most other semantic classes. For example, all and only verblike property terms may uncontroversially occupy the position provisionally marked " $\mathrm{x}$ " in the bare comparative of a discrepancy construction (schematized in (3)); stative and active verbs cannot usually occur in this position $(4 \mathrm{a}, \mathrm{b}){ }^{9}$

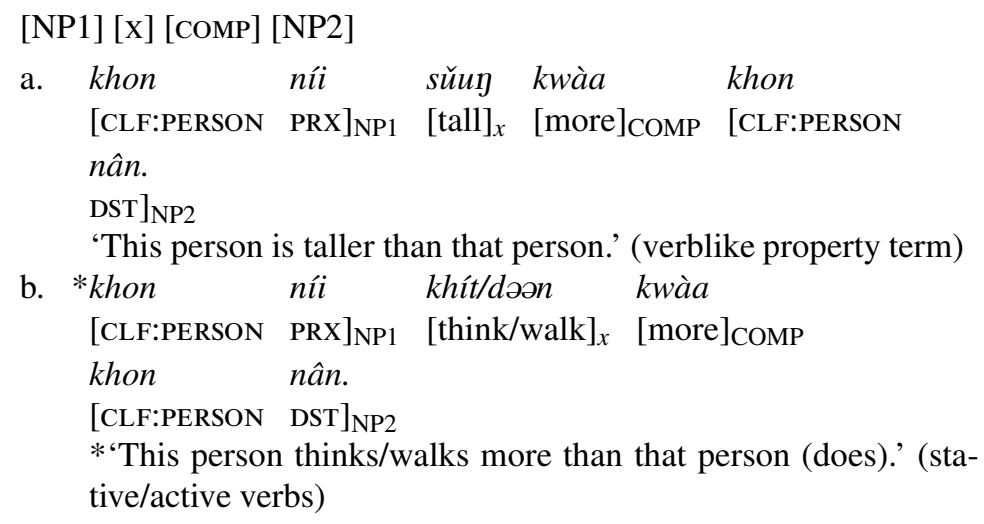

Although such distributional differences between active and stative verbs, on the one hand, and verblike property concepts, on the other, were sometimes marginalized by earlier analysts arguing for the basic verbal class-affiliation of property concepts in Thai, Enfield $(2004,2007)$ - in what is by far the most nuanced and consistently-argued treatment of the topic in any GMSEA language to date - was able to more sensitively identify such distributional differences as evidence for the coalescence of a distinct class of lexemes (in this case in Lao) whose semantic core was made up of property terms. Inasmuch as a distinct class of lexemes whose semantic core contains property concepts is traditionally assigned the label "adjective", Enfield was accordingly motivated to identify a class of adjectives in Lao. However - and this is the crucial point due to his identification of the predication construction as criterial for a higherlevel taxonomic classification of lexemes, Enfield concluded that adjectives in Lao do not constitute an independent class of lexemes (on a taxonomic par with noun and verb), but rather constitute a sub-class (in fact, a sub-sub-class)

\footnotetext{
9. Stative verbs which have the semantic versatility to be also treated as properties may occur in this position, although such examples tend to be rare. For instance, one may employ the stative verb rúu if and only if it is treated as a property ('be knowledgeable') rather than an event ('know a particular thing'), as well as mii 'have/exist' if it is treated with the sense 'be wealthy/in possession of much'. Notably, however, such verbs exhibit behavioural restrictions in this case (such as inability to take complements), and can effectively be treated as cases of cross-class (or cross-subclass) polysemy.
} 
Table 1. Properties distinguishing verb sub-types in Lao (Enfield 2007: 270)

\begin{tabular}{|c|c|c|c|c|c|c|c|}
\hline & $\begin{array}{l}\text { Prop- } \\
\text { erties }\end{array}$ & $\begin{array}{l}\text { Noun } \\
\text { (e.g., } \\
\text { maa3 } \\
\text { 'dog') }\end{array}$ & $\begin{array}{l}\text { V. } \\
\text { achieve- } \\
\text { ment } \\
\text { (e.g., } \\
\text { hên3 } \\
\text { 'see') }\end{array}$ & $\begin{array}{l}\mathrm{V} . \\
\text { accomplish- } \\
\text { ment (e.g., } \\
\text { tam1 } \\
\text { 'weave') }\end{array}$ & $\begin{array}{l}\mathrm{V} . \\
\text { activity } \\
\text { (e.g., } \\
\text { lèèn1 } \\
\text { 'run') }\end{array}$ & $\begin{array}{l}\text { V. } \\
\text { state } \\
\text { (e.g., } \\
\text { huu4 } \\
\text { 'know') }\end{array}$ & $\begin{array}{l}\text { V. } \\
\text { adjective } \\
\text { (e.g., } \\
\text { dii3 } \\
\text { 'good') }\end{array}$ \\
\hline \multirow{2}{*}{$\begin{array}{l}\text { Verb-only } \\
\text { properties }\end{array}$} & A & - & + & + & + & + & + \\
\hline & B & - & + & + & + & + & + \\
\hline \multirow{2}{*}{$\begin{array}{l}\text { Stative-only } \\
\text { properties }\end{array}$} & $\mathrm{C}$ & $\mathrm{n} / \mathrm{a}$ & - & - & - & + & + \\
\hline & $\mathrm{D}$ & $\mathrm{n} / \mathrm{a}$ & - & - & - & + & + \\
\hline \multirow{4}{*}{$\begin{array}{l}\text { Adjective-only } \\
\text { properties }\end{array}$} & E & - & - & - & - & - & + \\
\hline & $\mathrm{F}$ & - & - & - & - & - & + \\
\hline & $\mathrm{G}$ & - & - & - & - & - & + \\
\hline & $\mathrm{H}$ & - & - & - & - & - & + \\
\hline
\end{tabular}

A As NP modifier, linked by thiil

B As predicate, directly preceded by negator $b \grave{\varnothing} \emptyset$

C V with perfective marker, entails ' $\mathrm{V}$ now'

D Negation does not give future reading

E Type A reduplication

F Intensification with khanaat5 'really very'

G Comparative in frame NP1 _ kual NP2

$\mathrm{H}$ Superlative in frame $\mathrm{NP1}$ _thiil sut2

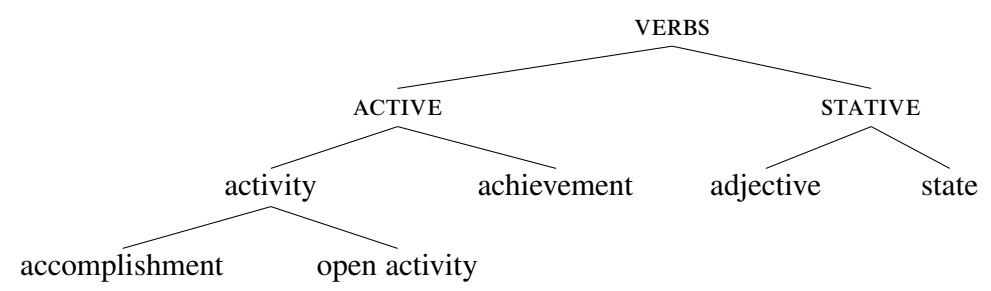

Figure 1. Taxonomy of Lao verb sub-types (Enfield 2007: 242)

of verbs. Enfield's main subclassification criteria, and the verb class-taxonomy for which they are the primary basis, provide a critical point of reference and are worth reproducing here (Table 1 and Figure 1).

In the remainder of this article, I will take the basic possibility to delineate, on distributional grounds, a class of terms whose semantic core includes property concepts in Thai to have been adequately demonstrated on the strength of data presented in (4) (and to be supplemented by data introduced below). 
Following Enfield (2004, 2007), I will refer to this class henceforth using the traditional label "adjective". This usage is not intended to entail any particular claim regarding the taxonomic or cognitive status of the class so labeled, however. Rather, following an expanded review of Thai adjectival distribution in Section 4, I will then return in Section 5.1 to the question of the lexical class-status of Thai adjectives, therein addressing the question of whether the distributional facts necessarily commit the analyst to a "verbal subclass" analysis such as that of Enfield (2004, 2007), or not, and whether (in either case) the Thai facts indeed do, or do not, provide evidence against an "adjectival universalist" argument as I will claim it should be properly construed. In most of what follows (and as in most previous studies of this nature), primary focus will fall on the relatively more numerous and diverse verblike property terms, since it is their behaviour that poses the clearest challenge to adjectival "universalist" claims as discussed in Section 2. Some discussion of the nounlike forms will be found in passing, and mentioned again in the final summary sections.

Before proceeding, a note on "grammaticality" in Thai: being a strongly isolating language, with little if anything in the way of "inflection" and acceptability often as much a matter of context-inherence as of well-formedness, it is very often the case that an "ungrammatical" example can be rendered "grammatical" through manipulation of intonation and construal. The target constructions of this article are, in some sense, the "basic" constructions of Thai, which would be normally open to the full range of applicable modifications and be either acceptable or unacceptable in pragmatically neutral contexts (to the extent that such contexts can be said to exist, for any language). Although examples in this article make use of individual forms, the claims to be made usually regard entire classes or subclasses of lexemes. Thus, while particular examples deemed "ungrammatical" herein in the sense intended may sometimes be rendered acceptable by means of a manipulation of intonation or construal, the skeptical reader is urged to assess the extent to which such acceptability judgments can or cannot be generalized beyond individual examples. ${ }^{10}$

10. For example - as pointed out by an anonymous reviewer - it is possible to imagine a situation in which the string of words in $(1 \mathrm{~h})$ would be an acceptable utterance; importantly, however, (1h) would not be acceptable in the same sense in which (1a, c, e) are, namely as an instance of a predication construction. Rather, acceptability here requires an intonationally-marked "topic-comment" presentation, as when running through a list of items (i.e., '(and as for) this person, (he's) a monk'). Tellingly, it is not possible (under any conditions) to relativize such a structure, as shown in (2h). I thank Kingkarn Thepkanjana and Pittayawat Pittayaporn for their insights on this topic. 


\section{Adjectives in Thai: An expanded view}

In this section, an expanded account of the behaviour and distribution of Thai adjectives is presented, with a primary focus on ways in which adjectives do or do not contrast distributionally with stative or active verbs.

\subsection{Class-changing derivations}

Class-changing derivations are commonly used as criteria for the identification of word classes, since they typically involve enabling a lexeme with basic membership in one particular word class to exhibit behaviour which is prototypically associated with lexemes from another word class. Equally, classchanging derivations may enable a particular subclass of lexemes to exhibit the behaviour of a different subclass; for example, applicatives may enable intransitive verbs to behave like transitive verbs (Aikhenvald 2007: 40-43). The forms and constructions in this section are usually described as having classchanging characteristics in one or the other of these two senses; however, it must first be noted that, unlike in more synthetic languages, in Thai a clear distinction among productive syntactic compositions [[WORD] [WORD]], compound lexemes [WORD-WORD], and complex derived lexemes [PFX-WORD] is not always easily made. For example, caj dii [heart good] 'nice, kind' has the syntactic composition of an adnominal attributive modification [N ADJ] (see Section 4.2); however, it and a number of other terms with initial formative $c a j$ - many of which appear to exhibit semantic shift, as with caj dii) - are usually analyzed by Thai grammarians and lexicographers as lexical compounds (Haas 1964: 127, Diller 1980, Matisoff 1986, Iwasaki 2002, Iwasaki \& Ingkaphirom 2005: Section 16). Sometimes, frequently-occurring compound initials usually not finals - also develop more abstract derivational functions, such as semantic classification (cf. DeLancey 1986, Enfield 2007: Section 7.3) and lexical class change. While some such forms may phonologically reduce, become de-stressed and more "prefix-like", they nevertheless often continue to resemble their lexical sources both phonologically and semantically in significant respects. Such forms have been described as prefixes or as "quasi-prefixes" (Iwasaki \& Ingkaphirom 2005) or by more type-specific labels such as "class term", for the semantically classifying variety. ${ }^{11}$

The forms to be described below are of this nature; while originating as compound initials (and, ultimately, as lexical words) and continuing to resemble them in some respects, they have semantically and functionally generalized; accordingly, they are treated by most Thai grammarians and lexicographers as

11. Naumann \& Vogel (2000) also mention the more general terms "pseudoaffix" and "affixoid", which might as easily be applied in this context. 
class-changing derivational word formatives, if not as prefixes in the strictest possible sense.

4.1.1. Nominalization. Most types of abstract nominalization in Thai are performed by one of two erstwhile lexical nouns khwaam 'sense, substance, gist' (Haas 1964: 81) and kaan 'work, affairs, matters' (Haas 1964: 29). Both nouns may be found in a few lexical compounds, basically with their literal senses as noted above, such as kaan-miay [work-state] 'politics' or ntakhwaam [meat-substance] 'essence of a matter'. More often though, they occur as abstract deverbal or deadjectival nominalizers. In this capacity, khwaam performs state or property nominalizations (5a), while kaan performs action nominalizations $(5 b)$.
a. khwaam dii
*kaan dii
SNZR good
ANZR good
'fastness'
b. *khwaam dəən
SNZR walk
'walking'
kaan dəən
ANZR walk

Sookgasem (1996) noted long ago that most terms nominalized in khwaam were notional adjectives, while most terms nominalized in kaan were notional verbs, as shown in (5). However, both Prasithrathsint (2000) and Enfield (2004) later pointed out that a large number of terms in both Thai and Lao may be nominalized by EITHER khwaam or kaan; in such cases, the term in khwaam has a more stative feel, while the term in kaan has a more active feel (6). Both Prasithrathsint and Enfield concluded that nominalization cannot therefore reliably distinguish adjectives from verbs.
a. khwaam khit
SNZR think
'thought (as a process); concept'
b. kaan khít
ANZR think
'(the act of) thinking'

However, the overlap is not random or unpredictable. Table 2 exemplifies the potential for terms from each of the prototypically adjectival semantic fields identified by Dixon $(1977,2004)$, together with five prototypically verbal semantic fields (adapted from Enfield 2004), to be nominalized by either khwaam or kaan.

As shown in Table 2 and in all cases tested for this article, terms from all core and two non-core adjectival semantic fields are exclusively nominalized 
Table 2. Capacity for nominalization by khwaam or kaan by semantic type

\begin{tabular}{|c|c|c|c|c|c|}
\hline \multicolumn{2}{|c|}{ Semantic field } & \multirow{3}{*}{$\begin{array}{l}\text { Thai } \\
\text { khăaw } \\
\text { dam }\end{array}$} & \multirow{2}{*}{$\frac{\text { English }}{\text { 'white' }}$} & \multirow{2}{*}{$\frac{\text { khwaam }}{\text { 'whiteness' }}$} & \multirow[t]{2}{*}{ kaan } \\
\hline \multirow[t]{8}{*}{ Core ADJ } & COLOUR & & & & \\
\hline & & & 'black' & 'blackness' & \\
\hline & AGE & $m a ̀ j$ & 'new' & 'newness' & \\
\hline & & $k a ̀ w$ & $\begin{array}{l}\text { 'old (non- } \\
\text { human)' }\end{array}$ & ‘oldness’ & \\
\hline & VALUE & $d i i$ & 'good' & 'goodness' & \\
\hline & & $j \hat{\varepsilon} \varepsilon$ & 'terrible' & 'badness' & \\
\hline & DIMENSION & sǔuy & 'tall' & 'tallness' & \\
\hline & & tîia & 'short' & 'shortness' & \\
\hline \multirow{6}{*}{$\begin{array}{l}\text { Non-core } \\
\text { ADJ }\end{array}$} & $\begin{array}{l}\text { SPEED } \\
\end{array}$ & rew & 'fast' & 'fastness' & \\
\hline & & cháa & 'slow' & 'slowness' & \\
\hline & PHYSICAL PROPERTY & róon & 'hot' & 'hotness' & \\
\hline & & năaw & 'cold' & 'coldness' & \\
\hline & HUMAN PROPENSITY & $c a j-d i i$ & 'kind' & 'kindness' & 'being kind' \\
\hline & & caj-ráaj & $j$ 'cruel' & ‘cruelty’ & 'being cruel' \\
\hline \multirow[t]{2}{*}{ Non-core } & $V$ STATE & rúu & 'know' & 'knowledge' & 'knowing' \\
\hline & ACHIEVEMENT & hěn & 'see' & 'opinion' & 'seeing' \\
\hline \multirow[t]{3}{*}{ Core v } & STATE CHANGE & tढेck & 'become broken' & & 'breaking' \\
\hline & ACCOMPLISHMENT & tam & 'weave' & & 'weaving', \\
\hline & ACTIVITY & dəən & 'walk' & & 'walking' \\
\hline
\end{tabular}

by khwaam while core verbs are nominalized exclusively by kaan. Distributional overlap is found in the semantic margins of the two classes, among HUMAN PROPENSITY and STATE/ACHIEVEMENT terms. The nominalization test therefore clearly does not reliably discover all and only the members of an adjective or verb class, as cited accounts have already indicated. However, it appears to discover an ordered relationship in the distribution of terms from two semantically-defined classes. Namely, it finds that while terms sharing like semantics pattern together, terms from the relatively dissimilar semantic cores of the two sets also contrast in their distribution.

4.1.2. Adjectivalization. At least three derivational formatives are commonly identified by Thai grammarians as characteristically adjectivalizing, in the sense that they all license terms which may occupy the nucleus of a bare comparative of discrepancy (cf. (3)), among other traits. These are: nâa- 'inducingto, -worthy', châay- 'having the characteristic of doing', and khîi- 'having the negative characteristic of doing, doing recklessly or impetuously' (Sookgasem 1996, Iwasaki \& Ingkaphirom 2005: 30-31). Arguably, such forms do not directly demonstrate the existence of a basic word class "adjectives" in Thai, into 
which terms from other basic word classes may be imported or transformed, but instead would reinforce a view that there is a fundamentally "adjectival" distributional pattern which is automatically open to (i.e., is prototypically associated with) basic adjectives, but which is closed to basic members of other word classes unless licensed by a derivational formative such as the below.

The basic function of $n \hat{a} a-$ 'AZR' is to derive an adjectival denoting the inherent potential of an Attributee to bring about a positive feeling in an Experiencer (usually, the speaker), were he/she to interact with the Attributee via an activity named by a following verb; roughly: 'of an entity, have/be of a quality such that it seems like it would be nice to experience interaction with in terms of VERB'. Lexically, nâa-mainly selects for transitive or extended-transitive verbs which project a sense of control onto the subject ( $\mathrm{S}$ of extended intransitive or A of (extended) transitive); ${ }^{12}$ nâa- does not in general select for non-controlled state verbs. Thus, nâa-ruucàk [AZR-know.someone] 'of a person, have a quality such that it seems like it would be nice to know them' is acceptable, but ?/*nâa-rúu [AZR-know] is odd. The resulting adjectival projects an Attributee $\mathrm{S}$ which is co-referential with the underlying O or E of the derived verb (i.e., the "person" of nâa-ruucàk). A sentence illustrating the grammaticality of active verb dəən 'walk' in the bare comparative of discrepancy when adjectivalized in nâa- is in (7) (to be compared with the ungrammatical sentence in (4b), in which dəən 'walk' is not adjectivalized).

$$
\begin{array}{lllllll}
\text { thanǒn } & \text { sên } & \text { nân } & \text { nâa-dəən } & \text { kwàa } & \text { sên } & \text { níi } \\
\text { road } & \text { CLF:LINE } & \text { DST } & \text { AZR-walk } & \text { more } & \text { CLF:LINE } & \text { PRX }
\end{array}
$$

'That road looks more walkable (better or more suitable to walk on) than this one.'

More rarely, nâa-can be seen to occur with adjectives - generally, those (like sanùk 'fun') which are not used to attribute inherent features or properties to their subject referents, but rather reference the capacity of a subject referent to produce some effect on an unmentioned Experiencer (usually, the speaker). However, nâa- does not generally occur with adjectives denoting (or which are construed to denote) inherent properties of entities.

Châay- 'having the characteristic of doing' derives from the lexical noun châay 'master, artisan', and forms N-N compounds such as châay-thoon [artisangold] 'goldsmith' in which it clearly retains its etymological sense. As a derivational formative it precedes verbs and derives an adjectival whose Attributee

12. The sense of "extended transitivity" used here is that of Dixon (2000), in which article the "syntactico-semantic" labels S, A, O, and E are also explained. Very briefly, S is understood as the single argument of an intransitive clause, $\mathrm{A}$ and $\mathrm{O}$ as the more agent-like and less agent-like arguments of a transitive clause, respectively, and E as the "third core argument" of an "extended transitive clause" (for example, an obligatory Beneficiary or Goal). 
is construed as habitually, characteristically, or expertly (or to an appreciable degree) bringing about the activity named by the verb. In this function, châan- is usually nuclearly reduced to chân-; examples are chây-phûut [AZRtalk] 'talkative', chây-khít [AZR-think] 'be quite a thinker', chây-kin [AZR-eat] 'be a big eater/lover of food'. Although examples are omitted in the interest of space, châa- also, like nâa-, licenses participation in the bare comparative of discrepancy; cf. (7).

Unlike nâa-, chây-can also prefix to adjectives - mainly, from the HUMAN PROPENSITY field - usually denoting a characteristic over which the Attributee may be construed as having some control, or which result from specific actions taken by the Attributee; examples are chân-khiikiat [AzR-lazy] 'terribly lazy' and chây-sŭaj [AZR-beautiful] 'really pretty'.

$K h \hat{\imath} i$ - 'having the negative characteristic of doing' derives from the lexical noun $k h \hat{i} i$ 'excrement' and forms N-N compounds such as khîi-burìi [excrementcigarette] 'cigarette ashes' in which its etymological sense is more or less evident, as well as others in which it simply marks the expression as negative in connotation or enhances an already-present negativity (as khîi-rt́an [excrement-leprosy] 'leprosy'). Prefixing verbs, $k h \hat{\imath} i$ - most often derives an adjectival with a sense similar to that of a term in chân-, but with a negative connotation: khîi-phûut [AZR-talk] 'motormouth-ed', khîi-koohòk [AZR-lie] 'habitually lying', $k h \hat{\imath} i$-liim [AzR-forget] 'forgetful'. More rarely, $k h \hat{\imath} i$ - prefixes to nouns, deriving an adjectival whose Attributee is viewed as habitually (often pathologically) associated with or experiencing effects of the mentioned entity, as khîi-jaa [AZR-medicine] 'drug addict, be a drug addict'. Here too, derivation in $k h \hat{\imath} i$ - licenses occurrence in the bare comparative of discrepancy (see above).

Khîi- also prefixes to some adjectives, most of them HUMAN PROPENSITY terms denoting non-inherent states which could as easily be analyzed as stative verbs (such as khîl-maw [AZR-drunk] 'be a drunkard'). It can also prefix to certain core adjectives which are capable of denoting inherent properties of an Attributee, such as khîi-róon 'be susceptible to heat' or khîi-năaw 'be susceptible to cold'. Importantly, however, the Attributee of the derived adjectival is NOT in this case understood as coreferential with the Attributee of the underived adjective. In (8), note that the Attributee subject of khîi-róon is not the Attributee of róon 'hot', but is rather construed as an Experiencer of the actions or effects of some unmentioned entity with the attribute 'hot' (seemingly, the weather).

$$
\begin{aligned}
& \text { phîi } \quad \text { khîi-róon mâak, mâj klâa thîi cà paj } \\
& \text { elder.sibling AZR-hot very.much NEG dare CTZR IRR go } \\
& \text { Postreelia. } \\
& \text { Australia } \\
& \text { 'I'm pathetically susceptible to heat; I don't dare go to Australia.' }
\end{aligned}
$$


To summarize the above, there are three adjectivalizing derivations in Thai, nâa-, châay-, and khîi-. All derive terms which have the basic distributional features of adjectives, primarily via prefixation to lexical verbs (far less often, to nouns). More rarely, they may also prefix to a limited set of adjectives. In general, however, they do not prefix to adjectives denoting inherent properties of entities unless the property is construed as obtaining of some entity OTHER THAN the Attributee of the derived adjectival. In other words, core adjectival senses do not fall within the selectivity of the prefixes.

\subsubsection{Adverbialization}

4.1.3.1. Zero-derivation. Some previous analysts, such as Haas (1964), have considered most Thai words which translate as adverbs in other languages to be in fact adjectives, and thus, ultimately, verbs (9).

$$
\begin{array}{llll}
\text { khăw phûut phaasăa thaj daj dii } \\
{[3]_{\mathrm{A}}[\mathrm{speak}]_{\mathrm{V} 1} \text { [language Thai] }} & {[\mathrm{can}]_{\mathrm{V} 2}} & \text { [good] }]_{\mathrm{V} 3 / \mathrm{ADV}} \\
\text { 'He can speak Thai well.' (Haas 1964: xx) }
\end{array}
$$

However, closer examination reveals this characterization to be somewhat incomplete. As Iwasaki \& Ingkaphirom (2005: Section 7.2) have shown, Thai adverbials may in fact be subdivided into (at least) five subclasses: manner adverbs, frequency adverbs, "miscellaneous" adverbs, temporal adverbials, and place adverbials. Of these, only manner adverbs include terms which are also used as adjectives; frequency adverbs - though sharing many behavioural and distributional characteristics with manner adverbs - cannot be used as adjectivals and/or verbals (for example, they cannot usually head an intransitive predicate or head an attributive or relative clause), while temporal and place adverbials more closely resemble, and could potentially be analyzed as, oblique noun phrases. Miscellaneous adverbs include terms denoting intensity and extent, among other things; they are highly idiosyncratic in distribution and functionality, and could potentially be further subclassified extensively. The subclassification of Thai adverbials might be provisionally represented as in Figure 2. In what follows we will be primarily interested in manner adverbs; examples of the use of other adverb(ial phrase) types may be found in Iwasaki \& Ingkaphirom (2005: Section 8).

Two points merit some elaboration here: the first is that not all adjectives may occur as manner adverbs. Generally speaking, adjectives which may readily occur as manner adverbs are drawn from the fields of SPEED, VALUE, and HUMAN PROPENSITY. Adjectives from the fields of COLOUR and DIMENSION seem never to occur as manner adverbs, and adjectives from the fields of AGE and PHYSICAL PROPERTY seem to be idiosyncratically distributed as manner adverbs; for example, màj 'new' can occur as a manner adverb with the sense 'newly, afresh' (10a), but its antonym kàw 'old (non-human)' cannot (10b). 


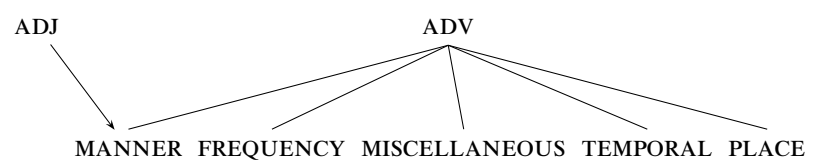

Figure 2. Derivation of (some) adjectives for use in manner subclass of adverb(ial)s
a. Paw màj.
[take $\mathrm{V}_{\mathrm{V}}[\mathrm{new}]_{\mathrm{ADV}}$
b. * Paw kàw.
take old.non.human
'(I'll) try/take it again/afresh.'

The second point is that Thai manner adverbs are both syntactically and semantically distinct from adjectives in usage, despite the fact that the vast majority of those forms which can occur in both adjectival and adverbial functions seem to reflect the same basic lexeme. In other words, while manner adverbs are almost always seemingly DERIVED from adjectives, it is not the case that they ARE adjectives. In a number of cases, semantic shift makes the case plain: in (11a), nàk 'heavy' occurs as a predicative adjective, while in (11b) the same lexeme occurs as a manner adverb. Note that the manner adverbial sense of $n a ̀ k$ 'hard, with great effort' - while clearly derived metaphorically from its basic adjectival sense - is not a direct reflex of the latter (i.e., it is not wholly predictable). ${ }^{13}$

$$
\begin{aligned}
& \text { a. Pan níi nàk mâak! } \\
& \text { CLF:GENR PRX [heavy very.much] }]_{\text {PRED }} \\
& \text { 'This one's really heavy!' } \\
& \text { b. khon níi rian nàk kwàa khon nân. } \\
& \text { person PRX study [with.effort more person DST] } \\
& \text { 'This person studies harder than that person (does).' }
\end{aligned}
$$

By contrast, verbs cannot normally be derived for use as manner adverbs. Here, it is important to distinguish cases of post-head serialization or verbal compounding - particularly, post-head result complements - from true manner adverbs. Although the latter may always undergo reduplicative intensification ((12a), cf. Section 4.3.1), the former never can. (12b) illustrates use of the resultative compound rian-rúu 'learn' (literally, 'study with the result that one

13. Note that this is not an artifact of the English translations, as Thai speakers readily identify the two senses as semantically distinct. At the same time, it is interesting to note that the closest English translation of adverbial nàk, namely 'hard', is itself a metaphoric derivative of a (different) PHYSICAL PROPERTY adjective. Clearly, we are dealing with a similar type of process in both languages. 
knows'), showing that the post-head verb rúu 'know' cannot be reduplicated (as though it were a manner adverb); (12c) simply shows that more active verbs cannot occur at all in this position, even if they are perhaps semantically plausible manner modifiers.

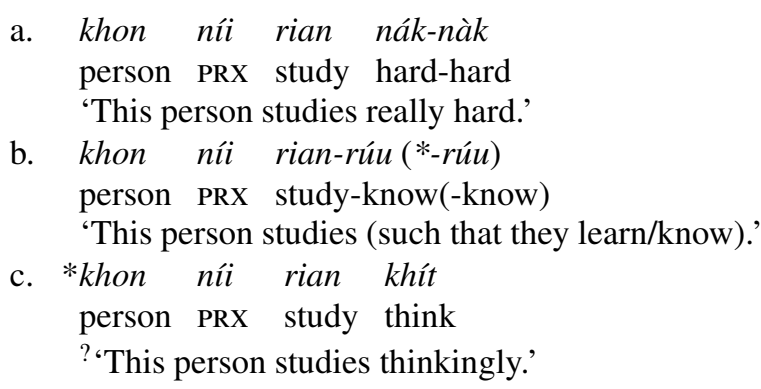

In sum, it is not the case that Thai adverbs and adjectives (and/or verbs) fully overlap. Rather, some though not all adjectives can be zero-derived for use as manner adverbs, while other subclasses of adverb bear no such relationship to the adjective class, nor to verbs (more generally).

4.1.3.2. Marked adverbialization. In addition to zero-derivation from adjectives, Thai has a morphological manner adverbializer jàay-. Derived from the lexical noun jàay 'kind, variety', jàan- continues to occur in several contexts whose senses derive directly from the nominal source form, as in compounds or fixed expressions such as jàay-nł̀n [kind-one] 'for one thing ...' . jàay also occurs as a classifier for 'kinds' or 'ways' and as a manner pronominal formative, in which capacity it is usually nuclearly and tonally reduced (as in jay-nán 'like that'). As a class-changing derivation, jàay- productively adverbializes adjectives (13a); it does not adverbialize verbs (13b).

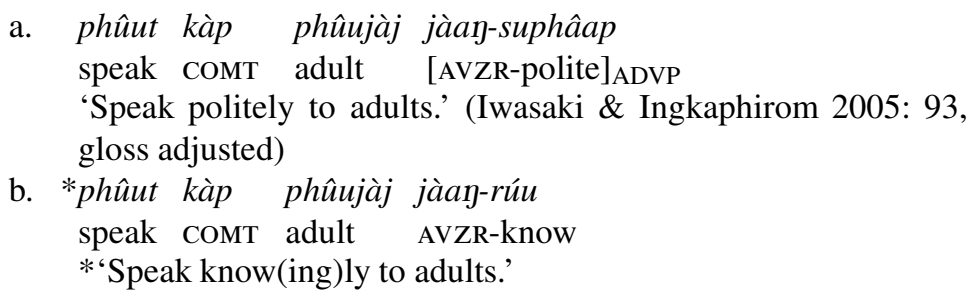

In most cases, an adjective under manner adverbialization in jàan- has a semantic value which is similar to the equivalent use under zero derivation (cf. Section 4.1.3.1). However, manner adverbialization in jàay- enables an adverbialized adjective to attain a greater degree of syntactic freedom than would otherwise be possible. Whereas manner adverbs which are zero-derived from 
adjectives tend to depend closely on the predicate over which they have scope (as in (11b)), use of jàay-as in (13a) enables the manner adverb to, for example, follow a noun phrase such as the object of a transitive verb; (14) shows that a jàan-less paraphrase of (13a) creates a scope ambiguity in which the adjective suphâap 'polite' might be interpreted either as a noun-modifying attributive adjective or as a verb-modifying manner adverb. ${ }^{14}$
phûut kàp phûujàj suphâap
a. speak COMT $\left[[\text { adult }]_{\mathrm{N}} \quad[\text { polite }]_{\mathrm{ADJ}}\right]_{\mathrm{NP}}$
'Speak to polite adults.' (noun-modifying attributive adjective)
b. speak сомт [adult $]_{\mathrm{N}}[\text { politely }]_{\mathrm{ADV}}$
'Speak to adults politely.' (verb-modifying manner adverb)

Such ambiguities do not occur when a marked adverbialization in jàan- is employed, as in (13a).

\subsection{Adnominal modification}

In Thai, adnominal modification by another lexeme may be direct or marked; in direct modification, a modifying lexeme is directly postposed to the head nominal, without any intervening linking material: [H MOD]. ${ }^{15}$ In marked modification, the relationship between the head nominal and its modifier is marked by an overt syntactic linker of some kind: [H LNK MOD]. Direct modification in Thai, as in many other languages, often has the semantic and syntactic properties of a lexical compound; namely, the resulting construction would tend to denote a type or class of thing in the cultural world, and it may have a syntactically irregular composition. By contrast, marked modification usually represents a clearly compositional syntactic phrase.

These principles are first illustrated by way of adnominal modification by a lexical noun (15).
a. ahăan dèk
$[\text { food }]_{\mathrm{H}}[\mathrm{kid}]_{\mathrm{MOD}}$
'baby food' (direct modification)
b. ahăan khǒoj dèk
$\left[\right.$ food $_{\mathrm{H}} \quad\left[\begin{array}{ll}\text { GEN } & \mathrm{kid}\end{array}\right]_{\mathrm{MOD}}$
'the kid's food' (marked modification)

\footnotetext{
14. Not all speakers accept meaning (14b ), which may be considered "low register" or to amount to a casual ellipsis of jàay-. To the extent that the actual or underlying presence of jàay- in this construction could be described as a syntactic requirement, it would amount to a statement to the effect that marking is REQUIRED to enable adjectives to function adverbially in postnominal environments.

15. Other terms describing the same concept include ZERO modification and BARE modification.
} 
Direct adnominal modification by adjectives (16a, b) and verbs (16c, d) is also possible in Thai. Note in these examples that there is no particular restriction on the type of notional relation obtaining between the modified noun and the underlying thematic roles ( $\cong$ valence) associated to its modifier; that is: while in (16a) nám 'water' is a notional Attributee of khěy 'hard', bâa 'crazy' in (16b) is not viewed as an attribute of jaa 'drug', but rather as a caused attribute of some other, unmentioned entity. Similarly, modification of khăaw 'rice' by the $\mathrm{S}=\mathrm{O}$ ambitransitive verb tôm 'boil (something), (be) boil(ed)' in (16c) can have either attributive or patientive senses, viz. 'rice which is in a boiled state' or 'rice which has been boiled by someone' (in either case denoting porridge). In (16d), jaay 'rubber' is underlyingly the Instrument (a noncore argument) of lóp 'erase' (examples from Iwasaki \& Ingkaphirom 2005: $38)$.

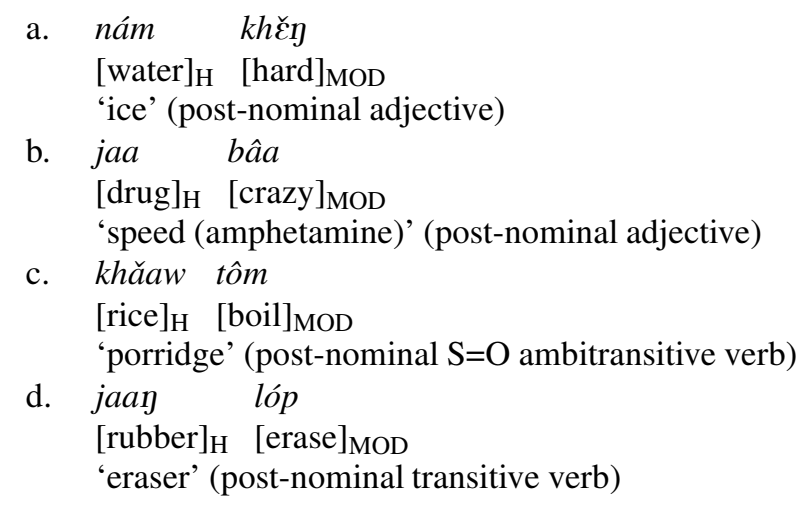

(16a-d) are examples in which a SINGLE TERM modifies the nominal head, and can be uncontroversially viewed as lexical compounds for reasons to be discussed below. However, Thai also of course has CLAUSAL adnominal modifiers; here too, direct and marked types can be identified. A direct clausal adnominal modifier formally consists of a gapped relative clause-like structure, directly postposed to the modified noun. Most often, the resulting composition identifies a class of entity in the cultural world, and is usually best translated into English via a pre-nominal participial (i.e., a cigar-smoking man). A marked clausal adnominal modifier exhibits the same gapped structure, but is linked to the head noun by a dedicated relativizer, most often thî 'REL' (a form which is derived from the lexical noun thîi 'place', and which also occurs in complementizing as well as locative and ordinal prepositional functions). ${ }^{16}$

16. Occasionally, Thai classifiers have also been treated as relativizing morphemes. While it is true that classifiers in relativization have an important individuating or contrastive function, 
Most often, the resulting composition constitutes a secondary assertion reflecting the speaker's judgement of some focal characteristic of a known referent; it is usually best translated into English via a relative clause construction (i.e., a man who smokes cigars). These two construction types will be described for Thai as an ATTRIBUTIVE CLAUSE (17a) and a RELATIVE CLAUSE (17b) respectively. ${ }^{17}$
a. khon
$\emptyset$ phûut phaasăa ankrìt
$\left.\left[[\text { CLF:PERSON }]_{\mathrm{H}} \varnothing \text { [speak language English }\right]_{\mathrm{MOD}}\right]_{\mathrm{NP}}$
chôsp maa ?ostreelia.
like come Australia
'English-speaking (Thai) people like to come to Australia.'
'The English-speaking (Thai) person likes to come to Australia.'
b. khon thîi phûut phaasăa ajkrìt
[[CLF:PERSON $]_{H}$ [REL speak language English $\left.]_{\text {MOD }}\right]_{N P}$
chôop maa Postreelia.
like come Australia
'(Thai) people who speak English like to come to Australia.' 'The (Thai) person who speaks English likes to come to Aus- tralia.'

As Kuno \& Wongkomthong (1981) have shown, Thai attributive clauses are functionally more restricted than Thai relative clauses. First, while relative clauses can seemingly reference any type of temporal frame, attributive clauses are restricted to relatively more time-stable (stative or inherent property-denoting) construals. In (18a), the speaker identifies a particular person whom the speaker asserts to be (currently) in the process of going to Japan, while the

they do not seem to be describable as syntactic relativizers per se; this is because the dedicated relativizer thîi can co-occur with a classifier, as in phuиjц̌n sǔaj [girl beautiful] 'beautiful girl', phuuǰ̄y khon sǔaj [woman CLF:PERSON beautiful] 'the beautiful girl', phuujı̌n khon thîi sǔaj [woman CLF:PERSON REL beautiful] 'the girl who is beautiful'; for discussion, see Hundius \& Kölver (1983: 177). Less commonly-used dedicated relativizers such as š̄ 'REL' usually occur in more formal speech register or in written Thai; in most functions, they too may co-occur with the general relativizer thîi. For discussion and examples, see Iwasaki \& Ingkaphirom (2005: 243).

17. In the Thai grammatical tradition, the differences between what we are here calling attributive clauses and relative clauses are often neglected. When they are recognized as distinct types of construction, attributive clauses are usually treated as types of compound, or as "compoundlike" relative clauses (cf. Iwasaki \& Ingkaphirom 2005: 250). That attributive clauses possess constructional properties which render them distinct from both lexical compounds (on the one hand) and relative clauses (on the other) - despite their sharing at least some of the features of both - was clearly shown in Kuno \& Wongkomthong 1981, and this analysis builds only slightly on their fundamental insights. However, the two constructions in question have not yet been contrastively labeled, nor would there appear to be a descriptive term in general use which covers the relevant functional contrasts. 
corresponding sentence in $(18 b)$ - in which being currently in the process of going to Japan is strangely construed as an inherent feature of a class of entity in the world - is unacceptable.

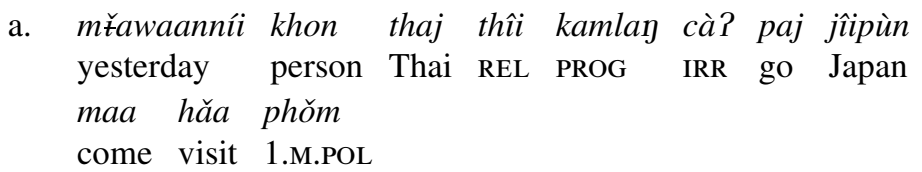

a. m̌̌awaanníi khon thaj thîi kamlay cà? paj jîipùn yesterday person Thai REL PROG IRR go Japan maa hăa phǒm come visit 1.M.POL

'Yesterday, a Thai person who is (in the process of) going to Japan came to see me.' (Kuno \& Wongkhomthong 1981: 216, gloss and translation slightly adjusted by the author) (relative clause)

b. *mřawaannii khon thaj $\varnothing$ kamlan cà? paj jîipùn yesterday person Thai $\varnothing$ PROG IRR go Japan maa hăa phǒm come visit 1.M.POL

?/*'Yesterday, an (in-the-process-of-)going-to Japan Thai person came to see me.' (attributive clause)

In addition, while Thai relative clauses permit modification of a wide variety of notional participant types, Thai attributive clauses can modify Attributee subjects only. ${ }^{18}$ Accordingly, an attributive clause modeled on the object relative clause of (19a) is unacceptable (19b).

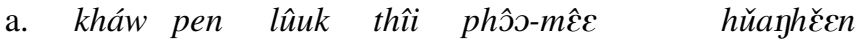 3 ACOP child [REL $_{\mathrm{i}}$ [father-mother $]_{\mathrm{A}}\left[\right.$ [treasure $_{\mathrm{VT}}$ $\emptyset \quad$ mâak
$\left.\left[\emptyset_{\mathrm{i}}\right]_{\mathrm{O}} \quad[\text { very.much }]_{\mathrm{ADV}}\right]$
'She is a child that (her) parents treasure very much.' (Iwasaki \& Ingkaphirom 2005: 249)

18. A number of temporal adverbial clause types exhibit basic [N (REL) CLAUSE] structure, including welaa (thîi) CLAUSE 'time (REL) CLAUSE' 'when CLAUSE' and ra ?wàan (thîi) CLAUSE 'interval (REL) CLAUSE' 'during CLAUSE'. However, the syntax of temporal adverbial clauses is somewhat different from that of attributive and relative clauses. First, temporal adverbial clauses do not generally contain a gap which is coreferential with the temporal nominal head (such as welaa 'time'). Second, presence or absence of the relativizer in a true temporal adverbial clause seemingly does not mirror the principles being described here (i.e., absence of the relativizer does not cause the referenced time to be understood as a class of entity in the cultural world); rather, presence or absence of the relativizer in a temporal adverbial clause may reflect weak grammaticalization of the temporal noun "heads" as dedicated markers of a temporal adverbial construction. If temporal adverbial clauses were included among attributive/relative clause types in Thai, then the overall description of the latter would change significantly. This is not the general practice in Thai linguistics, and is not the approach taken here; however, the question remains essentially open to research. 
Table 3. Properties of lexical compounds, attributive clauses and relative clauses compared

\begin{tabular}{lllll}
\hline & Compositionality & Modification & Semantics & Participant reference \\
\hline $\begin{array}{l}\text { Lexical } \\
\text { compound }\end{array}$ & Non-compositional & Direct & Denotes class & Idiosyncratic \\
$\begin{array}{l}\text { Attributive } \\
\text { clause }\end{array}$ & Compositional & Direct & Denotes class & $\begin{array}{l}\text { Attributee subject } \\
\text { only }\end{array}$ \\
$\begin{array}{l}\text { Relative } \\
\text { clause }\end{array}$ & Compositional & Marked & $\begin{array}{l}\text { Denotes } \\
\text { individual }\end{array}$ & $\begin{array}{l}\text { All core/non-core } \\
\text { participants }\end{array}$ \\
\hline
\end{tabular}

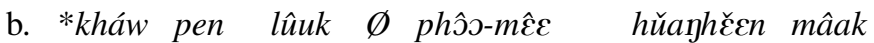

$$
\begin{aligned}
& 3 \text { ACOP child } \varnothing \text { father-mother treasure very.much } \\
& \text { *l? 'She is a (her-)parents-treasure-very-much child.' }
\end{aligned}
$$

To summarize, attributive clauses closely resemble lexical compounds, both formally (in being directly postposed to a nominal) and semantically (in denoting a class of entity in the cultural world). At the same time, attributive clauses are like relative clauses in being syntactically compositional rather than non-compositional or idiosyncratically compositional, and in implying a headcoreferential "gap". Accordingly, attributive clauses may be paraphrased via a relative clause construction - when appropriate semantic and pragmatic conditions exist - with no change in the basic denotation of the expression. By contrast, it is not possible to paraphrase most true lexical compounds via a relative clause without changing the denotation; for example, a relative clause paraphrase of (16b), jaa thîi bâa [medicine REL crazy] forces an Attributee subject reading 'medicine that is (itself) crazy', since this is the only type of participant role which may be ascribed to a relativized adjective in Thai. Finally, however, attributive clauses in Thai differ from relative clauses syntactically in permitting relativization on attributee subjects only, whether the relativized modifier is an adjective or intransitive/transitive verb; they do not license the set of relativizations on objects and non-core arguments which are licensed by relative clauses. Table 3 summarizes the similarities and differences among the three construction types.

The important point for present purposes is that adjectival adnominal modification would be expected to associate prototypically with the attributive clause type, while verbal adnominal modification would be expected to associate prototypically with the relative clause type. This would not be expressible as a strict syntactic constraint: as shown in (17a), attributive clauses CAN have as their nucleus an active, transitive verb, replete with a syntactically overt object noun phrase. However, the generalization should hold as a distributional ten- 
dency, in correlation with the intuitions of many Thai speakers that adjectival adnominal modification via a relative clause in context-free utterances tends to sound over-elaborated or emphatically contrastive, while verbal adnominal modification via an attributive clause may sound under-elaborated or elliptical.

To test this hypothesis, frequency counts were conducted on a set of eight Thai texts, elicited using the "Pear Stories" methodology and materials of Chafe and colleagues, as described in Chafe 1980. ${ }^{19}$ The target of the frequency count was adnominal modification by non-nominal forms. All instances of non-nominal modification were coded as "attributive" or "relative", and as nuclearly "adjectival" or "verbal". For present purposes, only adnominal modifications occurring in core or oblique argument noun phrases were considered; temporal adverbial clauses were not counted (see Footnote 18). The categories "attributive" and "relative" were defined in terms of presence or absence of a syntactically overt relativizer. The categories "adjective" and "verb" were defined via the set of criteria outlined elsewhere in this article, viz., ability to occur in a bare comparative of discrepancy, ability to undergo degree reduplication, etc., as well as on semantic grounds. Examples (20a-d) illustrate the four types of adnominal modification which were identified, viz., attributive/adjectival, attributive/verbal, relative/adjectival, and relative/verbal, respectively.

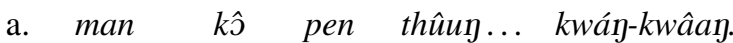

$$
\begin{aligned}
& \text { 3.NHUM SFOC ACOP field broad-broad } \\
& \mathrm{N} \quad \text { ADJ }
\end{aligned}
$$

'Well, it was a quite broad ... field.' (Attributive, ADJ)

b. chàak tòo maa bèp... mii khon cuuy

scene continue come HEST have/exist person lead

$\mathrm{N} \quad \mathrm{V}$

laa wăj

donkey move

'(In) the next scene like ... there was someone just leading a donkey along.' (Attributive, v)

c. k̂े ləəj Paw paj thán-mòt nìn takrâa thîi tem... SFOC really take go all one basket REL full

$$
\text { N REL ADJ }
$$

'(He) in fact went ahead and took all (of) a basket which was full.' (Relative, ADJ)

19. Speakers included two women and six men between the ages of 20 and 32; all were students at the University of Oregon. Texts varied from 3 to 9 minutes in length, with a mean of 4 minutes 35 seconds, and with an average word count of 855 . The text-collection was videotaped under controlled conditions at the University of Oregon Discourse Lab; all texts were then transcribed, translated, and analyzed with the assistance of native Thai speakers. 
Table 4. Number of non-nominal adnominal modifications, classified according to type. Total $A=$ Total number of mentions by lexical class $(A D J$ or $V)$; Total $B=$ Total number of mentions by modification type (Direct or Marked)

\begin{tabular}{|c|c|c|c|c|c|c|c|}
\hline & \multicolumn{3}{|c|}{$\begin{array}{l}\text { Number } \\
\text { (all texts) }\end{array}$} & \multicolumn{2}{|c|}{$\begin{array}{l}\text { Average } \\
\text { (per text) }\end{array}$} & \multicolumn{2}{|c|}{$\begin{array}{l}\text { Standard deviation } \\
\text { (per text) }\end{array}$} \\
\hline & Attributive & Relative & Total A & Attributive & Relative & Attributive & Relative \\
\hline ADJ & 58 & 3 & 61 & 7.3 & 0.4 & 5.5 & 0.7 \\
\hline $\mathrm{v}$ & 6 & 70 & 76 & 0.8 & 8.8 & 0.7 & 5 \\
\hline Total B & 64 & 73 & & & & & \\
\hline
\end{tabular}

Table 5. Frequency of non-nominal adnominal modification types, expressed as percents of total lexical class mentions

\begin{tabular}{|c|c|c|c|c|c|c|c|c|}
\hline \multicolumn{4}{|c|}{$\begin{array}{l}\text { Percent } \\
\text { (all texts) }\end{array}$} & \multicolumn{3}{|c|}{$\begin{array}{l}\text { Average } \\
\text { (per text) }\end{array}$} & \multicolumn{2}{|c|}{$\begin{array}{l}\text { Standard deviation } \\
\text { (per text) }\end{array}$} \\
\hline & Attributive & Relative & Total A & Attributive & Relative & Total A & Attributive & Relative \\
\hline ADJ & 95 & 5 & 100 & 95 & 5 & 100 & 10 & 10 \\
\hline $\mathrm{v}$ & 8 & 92 & 100 & 10 & 90 & 100 & 10 & 10 \\
\hline
\end{tabular}

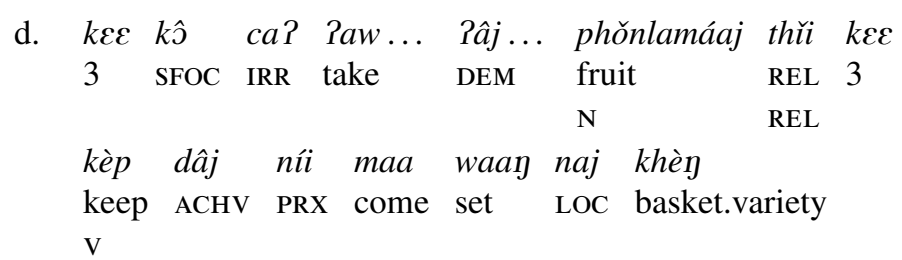

'Well, he would take the fruits that he managed to collect and put them in (his) basket.' (Relative, v)

The results of the frequency counts are presented in Tables 4 to 6; Table 4 expresses the numbers of each type of adnominal modification identified as fractions of the total number of adnominal modifications. Tables 5 and 6 express the frequencies of each type of adnominal modification identified as percents of total lexical class type mentions and adnominal modification type mentions, respectively.

Overall, the text counts revealed exceptionally strong correlations of adjectival adnominal modification with the attributive clause modification type, and of verbal adnominal modification with the relative clause modification type, at preference ratios ranging between 6.5 to 1 and 20 to 1 . Attributive clauses with a verbal nucleus were in general rare, with the majority of attested mentions not realizing core argument noun phrases, but instead realizing oblique 
Table 6. Frequency of non-nominal adnominal modification types, expressed as percents of total modification type mentions

\begin{tabular}{lcccccccc}
\hline & \multicolumn{2}{c}{$\begin{array}{c}\text { Percent } \\
\text { (all texts })\end{array}$} & & \multicolumn{2}{c}{$\begin{array}{c}\text { Average } \\
\text { (per text) }\end{array}$} & & \multicolumn{2}{c}{$\begin{array}{c}\text { Standard deviation } \\
\text { (per text) }\end{array}$} \\
\cline { 2 - 3 } & Attributive & Relative & & Attributive & Relative & & Attributive & Relative \\
\hline ADJ & 91 & 4 & & 87 & 3 & & 16 & 5 \\
V & 9 & 96 & & 13 & 97 & & 16 & 5 \\
Total B & 100 & 100 & & 100 & 100 & & \\
\hline
\end{tabular}

noun phrases with temporal or procedural content (such as in (20b)). ${ }^{20}$ Relative clauses with an adjectival nucleus were extremely rare, with only three mentions across all eight texts. Notably, in all three cases the "adjectives" in question were either tem 'full' or waay 'empty', both of which are perhaps only marginally to be considered as adjectives. ${ }^{21}$

In terms of discourse-functionality, it is important to note that adjectival adnominal modifications and/or attributive clause mentions most often occurred in the context of referent-introduction and/or description (as in (20a)), while verbal adnominal modifications and/or relative clause mentions most often occurred in the context of referent re-introduction and/or disambiguation (as in $(20 \mathrm{c}, \mathrm{d})$ ); this would seem to relate to the facts that adjectives and attributive clauses both prototypically refer to INHERENT PROPERTIES of entities - which could be expected to occur in contexts of reference-fixing in initial mentions - while verbs and relative clauses both refer prototypically to SPECIFIC EVENTS in which entities participate, in contrast to other possible referents (discussion along similar lines may be found in S. Thompson 1991 and Givón 1984). Accordingly, differences in discourse genre and/or in the construal of referents mentioned in a discourse could well lead to differences in the frequencies reported here (for example, the frequency of adjectival nuclei among relative clause mentions could well increase in a context in which the primary salient difference between two referents was their height); this question would require additional research into a corpus of larger size. The claim here, however, is that the correlations of adjectival modification with the attributive clause type, and

20. Since temporal or procedural noun phrases very closely resemble temporal adverbial clauses in structure and function, one might imagine that some common principles could govern the presence or absence of a relativizer in both cases. This remains a topic for additional research.

21. My consultants differed from one another concerning the ability of, for example, tem 'full' to occur in a degree reduplication, as well as with regard to some other tests. Although a decision was eventually made to treat both terms as adjectives, had they been treated as verbs the correlation of adjectival modification with attributive clauses in the database would have reached $100 \%$. 
of verbal modification with the relative clause type, reflect basic differences in both the semantics of adjective/verb classes and the discourse uses to which they tend to be put; the prediction is that these correlations should hold at some statistical strength in a Thai corpus of any size, and would under no natural circumstances be reversed.

\subsection{Degree constructions}

As was noted in Section 2 and in works cited in that section, degree constructions prototypically make reference to the GRADABILITY of concepts; that is, of the potential for a given concept to be construed as MORE or LESS the case. Accordingly, degree constructions might be expected to make special use of the inherent gradability of many prototypically adjectival property concepts (Hajek 2004) and, in general, that is found to be the case in Thai.

4.3.1. Reduplicative intensification. Reduplicative intensification of degree generally applies to monosyllabic lexemes only. Formally, it consists of one standard iteration of a target lexeme, preceded by an often nuclearly reduced iteration with a fixed rising tonal specification. ${ }^{22}$ Semantically, it entails an assertion to the effect that the target attribute is "indeed", "quite", or "certainly" the case. For example: mák-mâak 'very much' or súg-sǔu 'very tall' (from mâak '(very) much' and sǔug 'tall' respectively).

Much as in Lao (Enfield 2004), reduplicative intensification in Thai seems to apply only to monosyllabic terms which can be construed as gradable properties; in practice, this means that it applies to most if not all adjectives (21a) and adverbs (21b), but not to stative or active verbs (21c).

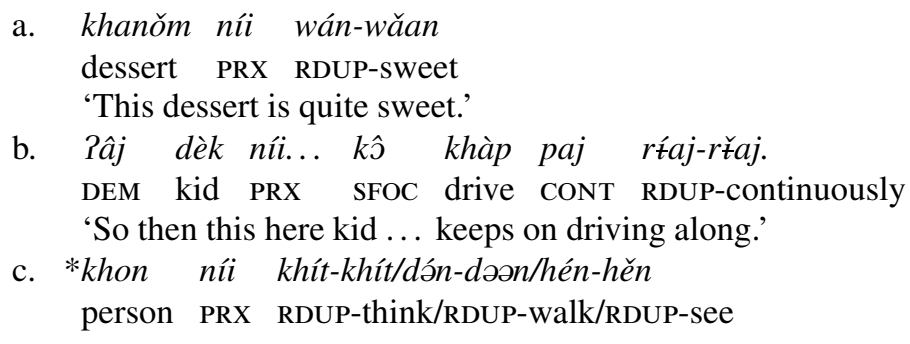

Accordingly, reduplicative intensification can be used as a criterion for distinguishing adjectives and adverbs from most stative or active verbs, but not

22. A distinct reduplication construction exists in which the initial formative carries an extra-high tone, and in which the nucleus is lengthened rather than reduced. This construction, which usually signifies that something is the case to an unusually great extent, is open to a wide variety of lexemes, including verbs, adjectives, and even most nouns. This latter construction should not be confused with reduplicative intensification as it is discussed here. 
for identifying all and only adjectives (since some adverbs which cannot occur in adjectival functions are also subject to reduplicative intensification, as in (21b)).

For some speakers, stative verbs are acceptable targets of reduplicative intensification, when and only when the target content can be construed as an inherent property of a referent (cf. also Footnote 9).

4.3.2. Marked intensification. Marked intensification of degree is accomplished via a variety of constructions in Thai, most of which can in their basic (or diachronically original) forms be described as adverbs or adverbials of frequency or intensity. As in many languages, Thai intensifiers are frequently and sometimes very rapidly innovated and may as easily fall out of use or survive only in fixed constructions. For example, the Lao adverb of intensity khanàat 'very (much), extensively' (from a noun meaning 'extent') occurs in Thai only in fixed expressions such as $n \hat{\varepsilon} \eta$ khanàt [crowded extent] 'very crowded'.

The most common Thai intensifier is an intensity adverb mâak 'very (much)'. Like several other adverbs of frequency and intensity - such as talı̀ot 'constantly' or cin 'really, indeed' - it can modify most if not all verbs (22a) and adjectives (22b), but usually cannot modify nouns (except when an existential predicate is ellipsed, but understood, as in (22c)). Most adverbs of manner, extent, frequency, or intensity can also be modified by mâak 'very (much)' (22d).

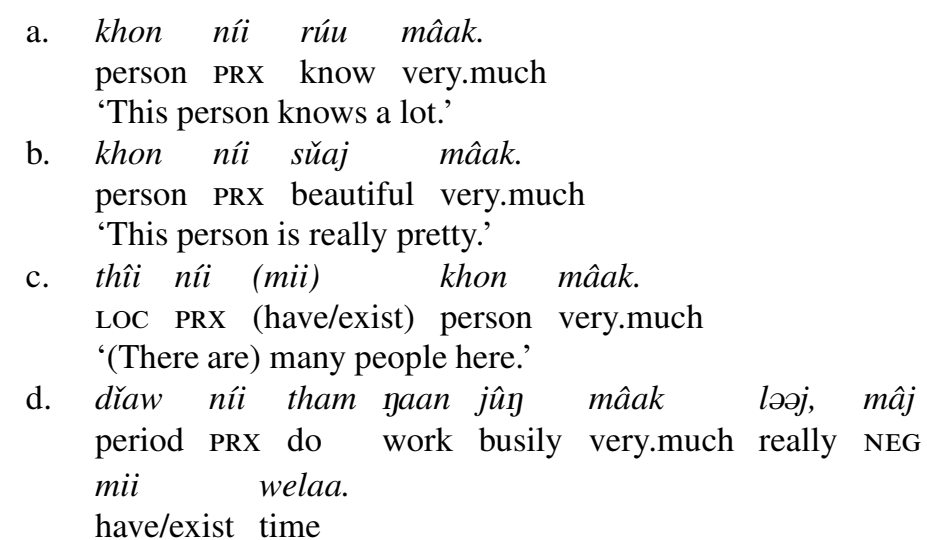
have/exist time

'At the moment I'm really working very hard/busily, I've no time (for anything else).'

Other intensifiers or intensifying constructions are more selective, and occur only with a subset of the available set of Thai lexemes; for example, can-ləəj 'indeed' is a compound adverb of intensity which most often occurs with adjectives and adverbs, and generally not with stative or active verbs (23a, b). 


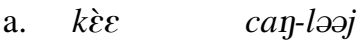
old.human indeed
'(He's) old indeed.'
b. *khit/*dəən caฤ-ləəj think/walk indeed

In some cases, intensifier selectivity must be further defined in terms of a semantically- and/or pragmatically-based lexical subclass. For example, chiaw 'utterly' may have an overblown or ironic feel, and for some speakers is restricted to adjectives denoting personal qualities with positive connotations (24a, b); however, is not generally used with stative or active verbs (24c).
a. wanníi sǔaj chiaw! today beautiful utterly
'You're looking simply divine today!'
b. ?'gaan ní jâak chiaw work PRX difficult utterly
?'This task is utterly difficult.'
c. *khit/*dəən/*hěn chiaw know/walk utterly

In many cases, intensifiers which cannot directly modify a verb can be licensed via modification of the verb in mâak 'very (much)'; compare (23b) with (25).

$$
\begin{array}{lll}
\text { khăw } & \text { khít } \quad \text { mâak } & \text { can-ləəj } \\
3 & {[\text { think }]_{\mathrm{V}}} & \text { [very.much }]_{\mathrm{ADV}} \\
\text { 'He really thinks a lot.' }
\end{array}
$$

In effect, then, cay-ləoj 'indeed' can be understood, in an example such as (25), to be a structural dependent of the adverb mâak 'very (much)', rather than of the verb per se, even though its semantic scope would appear to be over the predicate as a whole. In a similar fashion, mâak 'very (much)' can license verbal participation in a number of constructions denoting degree intensification which in their bare forms do not accept verbs (Sections 4.3.3-4.3.5). ${ }^{23}$

To summarize, the primary marked intensifier mâak 'very (much)' occurs readily with most if not all adjectives and stative or active verbs, as well as with adverbs, and in fact licenses the occurrence of stative or active verbs in several prototypically adjectival constructions. Other marked intensifiers are more selective, and may occur with only adjectives, or with a subset of adjectives and/or verbs.

23. Degree constructions capable of denoting decrease or reduction in degree can license verbal nuclei via post-nuclear adverb nóoj 'few, less'. 
4.3.3. Superlative constructions. Most intensifiers with a superlative value (-est/most) include the form sùt, originally a noun meaning 'end, extremity'. In the most common form of the superlative construction, sùt is preceded by thî $i$ (cf. Section 4.2), probably in an originally locative meaning. The resulting expression thîi-sùt 'the most' (lit., 'at (the) extremity') modifies adjectives (26a) and some adverbs, but not stative or active verbs (26b) or nouns (not shown).

$$
\begin{aligned}
& \text { a. khon níi key thîi-sùt } \\
& \text { person PRX clever the.most } \\
& \text { 'This person is the cleverest.' } \\
& \text { b. *khon níi khít/dəən/hĕn thî̀-sùt } \\
& \text { person PRX think/walk/see the.most }
\end{aligned}
$$

Other superlative expressions, most of which have a more colloquial feel, include sùt-jôst 'to the max' and the reduplicated form sùt-sùt. Again, both only modify adjectives (27a) and some adverbs, not verbs (27b) or nouns (not shown).

$$
\begin{aligned}
& \text { a. uui! phèt sùt-jôot ləəj! } \\
& \text { ExCL spicy to.the.max indeed } \\
& \text { 'Whoa! This is wickedly spicy!' } \\
& \text { b. *khít/*dəən/*hěn sùt-jôot } \\
& \text { think/walk/see to.the.max }
\end{aligned}
$$

As with simple intensification (Section 4.3.2), superlative modifiers of a verb can be licensed via mâak 'very (much)' (28).

$$
\begin{aligned}
& \text { khon níi khít mâak thî̀-sùt } \\
& \text { person PRX think very.much the.most } \\
& \text { 'This person thinks the most.' }
\end{aligned}
$$

4.3.4. Excessive construction. An excessive construction with the sense 'too/overly' occurs in (kəən)-paj, a compound whose optional initial formative derives from a verb or adverb with the basic sense 'exceed, excessively' (Haas 1964: 41), and whose final formative derives from the general verb of motion paj 'go'. The full form of the construction is available only to adjectives (29a) and some adverbs, but not to verbs (29b) or nouns.

$$
\begin{aligned}
& \text { a. man nàk kəən-paj } \\
& \text { 3.NHum heavy EXC } \\
& \text { 'It's too heavy.' } \\
& \text { b. *khăw khít/hěn/dəən kəən-paj } \\
& 3 \text { think/see/walk EXC } \\
& \text { *'He thinks/sees/walks too much.' }
\end{aligned}
$$


As with other types of degree modification, verbs are licensed to occur in the excessive construction via the intensity adverb mâak 'very (much)' (30).

$$
\begin{aligned}
& \text { khăw khít mâak kəən-paj } \\
& 3 \text { think very.much } \text { EXC } \\
& \text { 'He thinks too much.' }
\end{aligned}
$$

\subsubsection{Comparative constructions}

4.3.5.1. Comparative of discrepancy. The Thai comparative of discrepancy (' $x$ is more $q$ than $y$ ') has the basic form [NP1][x][kwàa][NP2]. NP1 and NP2 both realize notional Attributees of the adjective, and the property denoted by the adjective is viewed as obtaining to the referent of NP1 to a degree greater than that of NP2. ${ }^{24}$ The marker of the construction kwàa 'more' is a highly grammaticalized - probably very old - form with no obvious native Tai lexical source; found widely among Tai languages, including Lao, there is a chance that it may reflect an early loan from Chinese 过 (Mandarin guò) 'pass, cross'.

The nucleus of a bare comparative of discrepancy may be an adjective of any type (31a); it may not be a verb (31b) or noun (not shown). Many though not all types of adverb may serve as nucleus of a modified form of the bare comparative of discrepancy, in which a predicate nucleus stands for the NP1 slot in the above schematic (cf. (11b)). As with other degree constructions, a verb-nuclear comparative of discrepancy may be licensed via mâak 'very (much)' (31c).
a. khon níi sǔu kwàa khon nân person PRX tall more person DST
'This person's taller than that person (is).'
b. *khon níi khít kwàa khon nân person PRX think more person DST
c. khon níi khít mâak kwàa khon nân person PRX think very.much more person DST 'This person thinks more than that person (does).'

4.3.5.2. Comparative of equality. The Thai bare comparative of equality (' $x$ is as $q$ as $y^{\prime}$ ) has the basic form [NP1][x][thâw][NP2]. NP1 and NP2 both realize notional Attributees of the adjective, and the property denoted by the adjective is viewed as obtaining to the referent of NP1 to a degree equal to that of NP2. The marker of the construction thâw derives from a verb meaning

24. Another, far less frequently used form which can substitute for kwàa in this construction is jîn 'extremely'. 
'equal (in quantity/size)', and also occurs as a classifier for quantities as well as a quantity pronominal formative.

The nucleus of a bare comparative of equality may be an adjective (32a) but not an active or stative verb (32b) or noun (not shown). A verb-nuclear comparative of equality may be licensed via a preposition kàp 'with' (32c).
a. khon níi sǔuy thâw khon nân person PRX tall equal person DST
'This person's as tall as that person (is).'
b. *khon níi khit thâw khon nân person PRX think equal person DST
c. khon níi khít thâw kàp khon nân person PRX think equal with person DST 'This person thinks as much as that person (does).'

4.3.6. Inchoatives, state/property change, and degree intensification. Enfield $(2004,2007: 259)$ describes a variety of "directional complements" (verbderived post-head functors having directional semantics when used as a main verb) for Lao, all of which convey a sense of increased or intensified degree when following an adjective. The situation Enfield describes for Lao would appear somewhat more complex than that of Thai; in Lao, four such com-

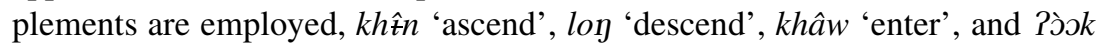
'exit' (employing the cognate Thai forms), and seem to resist an effective semantically-based description. Rather, adjective-complement collocations appear to be idiosyncratically conventionalized.

In Thai, only two forms khthn 'ascend' and log 'descend' are productive, and selection can be effectively characterized in most if not all cases. Generally speaking, adjectives denoting a property whose attainment is construed as positive or desirable preferentially take khthn 'ascend', while a negative antonym generally takes log 'descend'; a similar description is provided by Iwasaki \& Ingkaphirom (2005: 168-170) (33a, b).
a. caj-dii $k h \hat{t} n$
kind ascend
*caj-dii lon
'get nicer'
b. *caj-ráaj khthn
cruel ascend
'get crueler'
kind descend
caj-ráaj lon
cruel descend

Often, it is possible for a particular adjective to take inchoativization in either $k h \hat{t} n$ 'ascend' or loy 'descend'; in this case, selection appears to have little to do with value or connotation, instead indicating either intensification of the 
degree to which a property already obtains ( $k h \hat{t} n$ 'ascend' (34a)) or a change of state (lon 'descend' (34b)).

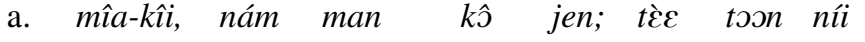 just.now water 3.NHUM SFOC cold DISJ time PRX

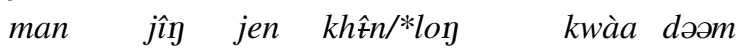 3.NHUM even cold ascend/descend more before 'Just a moment ago, the water was cold; but now, it's even colder than before.'

b. mîta-kíi, nám man jay róon jùu; toon níi just.now water 3.NHUM still hot stay time PRX

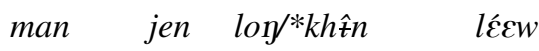
3.NHUM cold descend/ascend PFV

'Just a moment ago, the water was still hot; now, it's become cold.'

No stative verb may be directly inchoativized via $k h \hat{t} n$ 'ascend' or lon 'descend' (35a); however, a construction denoting increased degree can be licensed via post-verbal adverb mâak 'very (much)', while reduced degree can be licensed via post-verbal nóoj 'few, less' (35b).

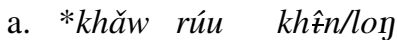

$$
\begin{aligned}
& 3 \text { know ascend/descend } \\
& \text { b. khăw rúu mâak khîtn. } \\
& 3 \text { know very.much ascend } \\
& \text { 'He knows more than before.' } \\
& \text { c. khăw rúu nóoj lọ. } \\
& 3 \text { know less descend } \\
& \text { 'He knows less than before.' }
\end{aligned}
$$

More active verbs which are followed directly by kht̂n 'ascend' or lon 'descend' are not inchoativized (unless followed by a degree adverb as in (35b, c)), but rather become specified for directionality (36). ${ }^{25}$

$$
\begin{aligned}
& \text { khăw dəən kht̂tn/lon } \\
& 3 \text { walk ascend/descend } \\
& \text { 'He's walking upward/downward.' }
\end{aligned}
$$

In sum, inchoativization of adjectives is accomplished via a post-head directional complement in $k h \hat{t} n$ 'ascend' or loy 'descend'. The same forms give directional meaning when following an active verb; they may not follow most

25. Inchoativization of verbs is handled via pre-head inceptive verb rə̂əm 'start', which may also occur with adjectives denoting controllable or non-inherent properties. 
other verb types. Inchoativization constructions thus successfully identify all and only adjectives in Thai.

\subsection{Predication, predication-based constructions, and predicate operators}

As was briefly discussed in Section 3, adjectives and verbs alike can stand as nucleus of a simple predicate in Thai, and do not occur as a copula complement, unlike nouns. As is discussed in more detail in previous works such as Prasithrathsint 2000 and Enfield 2004, among others, a large number of constructions and grammatical operators which relate fundamentally to the function of predication in Thai and some related languages accept both adjectival and stative or active verbal heads; important examples include common behaviour under negation, common formation of polar questions and answers, common ability to be modified by Irrealis $c a$ ? and Perfective lécw, and so on. However, there is in fact a huge number of predication-based constructions and predicate operators in Thai (most of which are, or are based on, serial verb constructions), and the majority have not yet been conclusively analyzed in terms of their selectivity for adjectival and/or stative or active verbal heads. To attempt to do so here would transform this article into a partial exegesis of the entire Thai predicate grammar, well exceeding its intended scope; however, a handful of relevant constructions can be usefully noted.

Post-verbal potential operator $d \hat{a} j$ selects for verbs denoting actions or states whose potential to obtain in particular conditions can be subject to question or doubt. Accordingly, although use of $d \hat{j} j$ 'РОТ' may be disallowed in constructions with a stative verbal nucleus such as rúu 'know', when the state denoted is construed to inhere as a permanent or non-controllable property of an entity. However, when states are clearly construed as POTENTIALLY inhering, use of post-verbal $d \hat{a} j$ is generally possible; for example, (37) might be used when discussing an individual's entitlement to learn a particular secret, but could not be used to question the nature of an individual's assimilated knowledge.

$$
\begin{array}{lllll}
\text { phîi } & \text { nóoj rúu } & \text { dâj } & \text { máj? } \\
\text { elder.sibling } & \text { little know } & \text { POT } & \text { PQ }
\end{array}
$$

'Can Elder Sister Noy know (the secret which you've just told me/*the answer to a question which she has been asked)?'

By contrast, post-verbal $d \hat{a} j$ 'POT' cannot generally occur with predicative adjectives, which function primarily to attribute properties to a referent (whose potential to inhere is not subject to question). Accordingly, (38) is unacceptable unless it is construed as having an ellipsed verbal predicate naming a particular type of event (in which case dii would have a syntactically adverbial rather than adjectival function). 


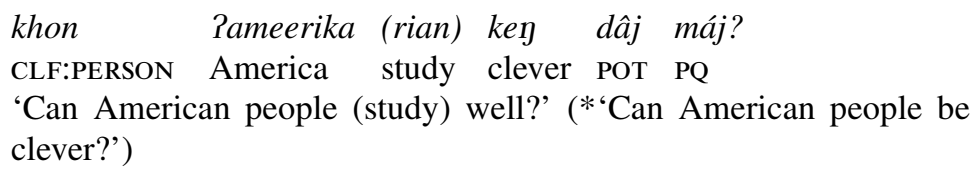

Similar arguments can be adduced in the case of pre-verbal Achievement operator $d \hat{a} j$; for example, dâj dəən [ACHV walk] 'manage to walk' is possible but *dâj dii [ACHV good] cannot mean *'manage to be (a) good (person)' (it is acceptable in case dii is interpreted as an adverb meaning 'well', in which case either $d \hat{j} j$ in its lexical sense of 'manage (to do something), succeed' or a second, ellipsed verb must be analysed as the syntactic predicate head). These facts would seem to contrast with those reported by Enfield (2004) for Lao.

Certain serial verbs which introduce complex temporal semantics, such as post-verbal Inchoative perfect maa 'come, IPF', select for relatively less timestable state and action verbs, and not for relatively more time-stable property adjectives (39a, b).

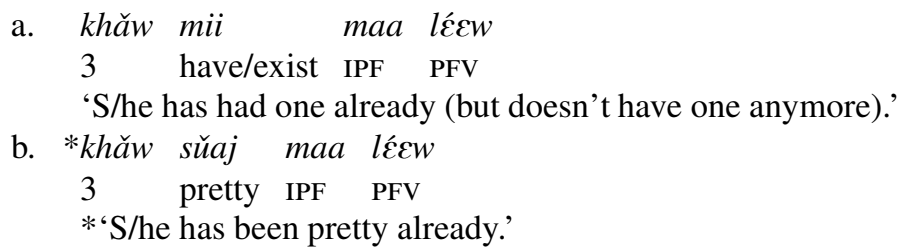

Finally, we can note that there are several predicative constructions and predicate operators which apply to all adjectives and some stative verbs, or to all verbs and some peripheral adjectives, but which cannot identify all and only adjectives in opposition to verbs. For example, the Perfective in lécw 'PFV, already' gives a change-of-state reading to all adjectives and to most stative verbs (i.e., 'is hot now (having not been before)'), but imparts a completive sense to active verbs (i.e., 'has walked already (has completed that event)') (Iwasaki $\&$ Ingkaphirom 2005: Section 12). And, the bare imperative (potentially supported by a post-head particle such as ləəj 'indeed' or sii 'why don't you') may generally be used with active verbs and some but not all stative verbs, and not with adjectives.

This brief presentation only begins to scratch the surface of the relevant set of behavioural possibilities and constraints; as mentioned above, a full presentation would exceed the scope of this article. The point, however, has been to show that to the extent that adjectives can occur as predicate heads in Thai, it is not the case that they exhibit the full range of possibilities available to stative or active verbs. Rather, there would seem to be several restrictions which apply only, or mostly, to adjectives. 


\subsection{Summary of distribution}

Table 7 summarizes the distribution of Thai adjectives and (other) verbs, in terms of the constructions identified in this article. As Table 7 shows, there is no question that all and only adjectives can be distinguished from stative and active verbs in Thai on distributional grounds. Just as importantly, however, even in those cases when distributional overlap occurs, it is neither random nor unpredictable. Rather, it is higher among peripheral members of both classes and lower among core members (in the senses of "core" and "peripheral" outlined in Section 2). In other words, with respect to their structural properties core adjectives and core verbs are maximally distinct in Thai, while peripheral classes are more likely to show overlap with other classes. ${ }^{26}$ In addition, overlap is low or non-occurring among prototypically adjectival or verbal constructions (such as degree constructions or event-oriented verb serialization), and high or complete among constructions prototypically associated to both classes (such as intransitive predication).

\subsection{Nounlike property terms}

In Section 3 we also discussed NOUNLIKE property terms, but did not include them in the discussions of Thai adjectival distribution in the subsections above. This is because, in general, nounlike property terms distribute more like nouns, and unlike verbs and verblike property terms (i.e., adjectives), in the majority of attested cases. However, it is also the case that nounlike property terms do not distribute like prototypical nouns in potentially significant respects. For example, it is difficult to use many (if not most) nounlike property terms to refer directly to either concrete entities or to abstract concepts (40a). Instead, it is more common to nominalize a nounlike property term construction under predication in pen 'ACOP' or a similarly predicative functor (40b). This is consonant with the property-denoting semantic content to nounlike property terms and the prototypically (concretely or abstractly) referential functions of nominals in most types of construction.

$$
\begin{aligned}
& \text { a. * sùantua pen sìn thîi dii. } \\
& \text { private ACOP thing REL good } \\
& \text { b. khwaam pen sùantua pen sìn thîi dii. } \\
& \text { SNZR ACOP private ACOP thing REL good } \\
& \text { 'Privacy/being by oneself is a good thing.' }
\end{aligned}
$$

Sometimes, nounlike property terms exhibit more "verblike" distribution, although variation both among constructions and among consultants' acceptabil-

26. See Pustet (2003: 153-184) for comparable lexical prototype effects tackled from a slightly different perspective, which is, however, compatible with the present author's approach. 
Table 7. Summary comparison of adjectival and verbal distributions in selected Thai constructions

\begin{tabular}{|c|c|c|c|c|}
\hline \multirow[t]{2}{*}{ Distributional feature } & \multicolumn{2}{|c|}{ ADJ } & \multicolumn{2}{|c|}{$\mathrm{V}$} \\
\hline & Core & Peripheral & Peripheral & Core \\
\hline Intransitive predication & yes & yes & yes & yes \\
\hline Intensification in $m \hat{a} a k$ & yes & yes & yes & yes \\
\hline Inchoative perfect & yes & yes & yes & no \\
\hline Stative nominalization & yes & yes & some & no \\
\hline Change of state perfective & yes & yes & some & no \\
\hline Completive perfective & no & no & some & yes \\
\hline Pre-head potential & no & no & some & yes \\
\hline Bare imperative & no & no & some & yes \\
\hline Post-head potential & no & no & yes & yes \\
\hline Post-head inchoative & yes & yes & no & no \\
\hline Zero adverbialization & yes & yes & no & no \\
\hline Marked adverbialization & yes & yes & no & no \\
\hline Reduplicative intensification & yes & yes & no & no \\
\hline Superlative intensification & yes & yes & no & no \\
\hline Excessive construction & yes & yes & no & no \\
\hline Comparative of discrepancy & yes & yes & no & no \\
\hline Comparative of equality & yes & yes & no & no \\
\hline Attributive clause & frequent & frequent & rare & rare \\
\hline Relative clause & rare & rare & frequent & frequent \\
\hline Adjectivalization in $n \hat{a} a-$ & no & some & yes & yes \\
\hline Active nominalization & no & some & yes & yes \\
\hline Copula complement & no & no & no & no \\
\hline
\end{tabular}

ity judgements in this area would appear high. For example, sòot 'single (not in a relationship)' is attested as both intransitive predicate and copula complement and can be nominalized in khwaam just like a verblike property term (41).

$$
\begin{array}{llllll}
\text { khwaam (pen) sòot pen sìn thîi dii. } \\
\text { SNZR (ACOP) single ACOP thing } & \text { REL good } \\
\text { 'Being single is a good thing.' } & & &
\end{array}
$$

Similarly, some nounlike property terms can take adjectival inchoatives; seemingly, if and only if the property denoted can be construed as suddenly coming to be the case (rather than as an intensification of degree) (42).

$$
\begin{aligned}
& \text { rót khan níi sanǐm kht̂n lécw! } \\
& \text { vehicle CLF:VEHICLE PRX rusty ascend PFV } \\
& \text { 'This car has (suddenly/unexpectedly) become rusty!' }
\end{aligned}
$$


My intention here is not to claim that nounlike property terms "are adjectives" in the same sense that verblike property terms have just been described as "adjectives", nor that there is a clearly identifiable superordinate category "adjective" in Thai which contains both nounlike and verblike property terms. Rather, the claim made here is that nounlike property terms and verblike property terms alike appear to exhibit distributional contrasts with the major classes to which they are closest, respectively, and that these contrasts - and, potentially, the areas in which they themselves coincide distributionally - relate fundamentally to their semantic status as property terms. This view would be consonant with the view that adjective classes crosslinguistically may be a type of "functional sink" into which terms from diverse lexical classes have the potential to be "pulled", as suggested by DeLancey (2001).

\section{Summary}

\subsection{The sense in which there "are (no)" adjectives in Thai}

As noted at the outset of this article, a number of analysts have suggested that there "are no" adjectives in Thai. In this section, we will clarify the sense in which such a statement can be said to be true. But first, we look at one sense in which it cannot be said to be true, by comparing it with the statement, "there are no sortal classifiers in English". Very briefly, I understand sortal classifiers to be a potentially open, nounlike class of terms which accomplish (very roughly speaking) definite reference to individuals or enumerated groups of individuals by invoking their status as exemplars of a particular semantic type (Hundius \& Kölver 1983). Thai is a paradigm example of a language with extensive sortal classifier use: (43a) shows that an enumerated noun phrase headed by phûuchaj 'male' is unacceptable in absence of a qualifying sortal classifier such as khon 'CLF:PERSON', while (43b) simply demonstrates that there is no acceptable English equivalent to the Thai structure exemplified in (43a).

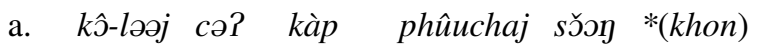

$$
\begin{aligned}
& \text { in.fact meet COMT male two CLF:PERSON } \\
& \text { 'And so they in fact encountered two guys.' } \\
& \text { b. And so they in fact encountered two (*persons (of)) males. }
\end{aligned}
$$

The syntactic position occupied by the sortal classifier khon 'CLF:PERSON' in (43a), and other syntactic positions available to sortal classifiers, can be filled by any of a very large and potentially open class of terms, subject to selectional compatibility with the classified head noun. In English, there is neither a syntactic position corresponding to classification of individuals, nor a candidate class of terms available for use in this or other, similar functions. The sense in which English "does not have" sortal classifiers is thus straightforward: they 
are completely absent from the language, whether as a functional category, as a structural category, and/or as a class of terms. ${ }^{27}$

By contrast, evidence reviewed in this article has suggested that, contrary to claims made by at least some previous analysts, there is in fact sufficient evidence in Thai to identify, on distributional grounds, a class of lexemes whose semantic core includes property concepts, which occur in crosslinguistically prototypical adjectival functions, and which would therefore normally be labeled "adjective" in traditional grammar. Furthermore, as was briefly discussed in Section 4.5, the evidence is non-arbitrary; instead, the distributional contrasts and overlaps among adjectives and stative or active verbs quite clearly reflects both the semantic core-peripheral organization of adjective and verb classes crosslinguistically and the syntactic and pragmatic uses to which they are prototypically put.

Thus, I maintain that it is not correct to claim that there "is not" a class of adjectives in Thai in the same sense that there "is not" a class of sortal classifiers in English. Rather, there "is" a class of terms in Thai which closely resembles the adjective classes of many other languages in terms of semantic contents, internal structure, and distribution relative to other lexical classes, and this class should therefore bear the label "adjective". Accordingly, the only sense in which it makes sense to say that there is not a class of adjectives in Thai is the sense outlined by Enfield (2004, 2007), in which adjectives are grouped together with verbs at a HIGHER TAXONOMIC LEVEL than that at which adjectival class-defining criteria are construed as applying. This point is addressed in the next section.

\subsection{Implications for a functionalist typology of word classes}

Returning now to Enfield's (2004) disagreement with Dixon (2004) concerning the taxonomic position of adjectives in the Lao lexicon, it should first be made clear that this article has probably not provided evidence which would undermine Enfield's analysis on its own terms to any extent. Instead, my intent here is to suggest that a number of methodological questions are raised by the

27. An anonymous referee points out that English "pluralia tantum" such as scissors may be argued to require a quantifier pair in the context of individual-enumeration; seemingly, this would argue in favour of treating pair as a sortal classifier. While one might concede the point and simply state that the case for sortal classifiers in English is at best marginal (i.e., there is not a full and well-defined class), it seems to me that one might as easily treat scissors as belonging to a non-prototypical subclass of plural noun which simply lacks a singular counterpart due to the effective non-occurrence of such an entity in the cultural world. In other words, there is no reason to view the syntax of a pair of scissors as being any different from a pair of fingers - both would be simply viewed as quantifier constructions, and the lack of a sortal classifier form and construction in English would thereby remain absolute. 
decision to stipulate taxonomic criteria in the description of lexical classes, all of which have important theoretical consequences:

The first question is whether there is, in fact, a commonly-agreed-upon, independently verified set of criteria for the taxonomic organization of word classes across languages. If there is such a set of criteria, it would enable the analyst to determine (i) the taxonomic position of the class of adjectives in language $x$, (ii) whether this position is the same as or different that that found in language $y$, and (iii) at what point, precisely, the historical ancestor * $x$ of language $x$ came to, for example, "have" adjectives which were represented as an independent lexical class (when at an earlier stage, they were represented as a lexical subclass). Unfortunately, however, there is no such commonly-agreed-upon set of crosslinguistically applicable criteria, despite many decades of research into the question. This would seem to leave all of (i)-(iii) inherently indeterminate, except as matters of aesthetic preference, opinion, or tradition.

The second question is whether categorical taxonomies in fact have any cognitive reality to speakers of a language (and therefore, any real theoretical status) at all. That is to say, given a set of forms $A-C$ which distribute in constructions $D-F$ in a particular way in language $x$ - leading to the stipulation of a taxonomy $T$ - and given a different distribution in language $y$ - leading to the stipulation of taxonomy $T^{l}$ - although it may be the case that different $\operatorname{cog}$ nitive facts underlie the differences in distribution among forms in languages $x$ and $y$, these facts may be exhaustively describable in terms of the forms and constructions themselves; it does not necessarily follow that the taxonomy which is in turn stipulated by the analyst has any cognitive reality. ${ }^{28}$

As Croft (2001) has argued in considerable detail, methodological inheritances from structuralism (carried through generativism) continue to compel even functionally and/or typologically-oriented grammarians to view lexical classes as though they were structural entities which project (as part of their underlying categorical specifications) precisely those behavioural characteristics in terms of which they are identified and defined. But this has never been demonstrated to be either necessary or, indeed, tenable in any well-motivated, theory-external sense. It is precisely this inherited bias toward viewing lexical classes as categorial entities which a language either "has" or "doesn't have", or which language $x$ "has" in some particularly significant way but which language $y$ "has" in some relatively insignificant way that leads to the construal of disputes such as that between Dixon (2004) and Enfield (2004) as being of high theoretical significance for typology and linguistic theory (cf. Evans 2005 and Newmeyer 2007). It is my contention (again, following Givón 1984 and Croft 2001) that the inherently unanswerable question "Are there adjectives in

28. Similar objections are raised by Croft (2005). 
language $x ? "$ - the source of most current disputes on the matter - would be better replaced by the question "Does every language treat its property terms in some ways differently from terms corresponding to other semantic classes, and are these ways similar across languages, or are they different?". A number of other, potentially even more productive, research questions naturally follow from this question, however it may be answered. Are there languages with typological profiles which are similar to that of Thai, but in which adjectives occur as copula complement rather than as intransitive predicates? If so, what are the specific synchronic and diachronic properties of copulas in these languages, and how may they differ, if they do, from copulas in Thai? Is there a relativizer in that language which selects for verbs, but not adjectives, and how may that fact be explainable in terms of the lexical source form of the relativizer and the properties of its historical bridge construction - and how might that contrast with the history of relativizers in Thai? And so on. All such questions would bear on the larger question of how property terms co-evolve with other elements of a language to distribute in the way that they do in particular cases; it is this question that we should be trying to address, rather than the inherently unanswerable question of whether or not a putative structural category with undefinable properties is or is not instantiated in two languages with incommensurate structures.

\section{Conclusion}

One can perhaps understand the strength of past reactions among Mainland South-East Asianists to the imposition of a structurally pre-determined "adjective class" upon their languages; with grammarians in the generative tradition, such as Baker (2003), continuing to insist upon pre-defined "universal" specifications on a structural/behavioural basis (and upon the existence of "covert" operators to "account for" languages which do not match pre-defined specifications), one feels a certain compulsion to underscore the fallacy of such analyses by banishing all mention of the offending category. But such reactions inevitably end up going too far, and risk purging the very grounds for discovery of a real and sensibly-construed linguistic universal in the process. ${ }^{29}$ Discovery of a linguistic universal "adjectives", properly defined, requires establishment of no single necessary and sufficient formal criterion such as "occurs as copula complement"; what it requires is the discovery that no language

29. There are also serious practical objections to the banishment or suppression of the adjective class as a point of reference in Tai linguistics. For example, searchable Thai text corpora which decline to employ the label "adjective" in tagging lexemes virtually preclude the possibility of conducting comparative distributional research in those areas where adjectives may contrast distributionally with verbs. 
fails to develop grammatical means of treating property concept words differently from other types of term. The typologically-oriented prediction of Dixon (2004) that adjectives (so defined) will be found in every language can be falsified through discovery of a language in which property concept words are in fact NOT treated in any way differently from another well-defined type of term (say, verb or noun); the argument made in this article is simply that Thai does not qualify as such a language, and that data from Thai thus fail to falsify the typologically-oriented claim.

In fact, however, we are still very far from being able to properly characterize the constitution of the Thai class of adjectives on its own terms, inasmuch as no complete distributional analysis appears to have yet been made available for Thai nor, indeed, for any natural language (i.e., what is the potential for EVERY candidate adjective to occur in EVERY relevant slot in EVERY relevant construction in the language under EVERY type of pragmatic conditions or construal?). This is the scale of the work which remains to be done, and on which our energies should be more closely focused henceforth.

Acknowledgements: An early draft of this article was presented at the 13th meeting of the South East Asian Linguistics Society at the University of California at Los Angeles in 2003, for which support was provided by a grant from the University of Oregon Department of Linguistics. Valuable comments have been received at various points from R. M. W. Dixon, Nick Enfield, Renée Lambert-Brétière, Doris Payne, Pittayawat Pittayaporn, Eric Pederson, Stephen Morey, and Kingkarn Thepkanjana. I especially thank my primary Thai consultants Waranon Chaiyot, Wipaporn Ariyamongkolchai, and Duangkamol Sutthiwari, all of whom contributed important insights and information, in addition to providing much of the data presented herein; however, any remaining errors are mine.

Data collection and transcription: Except when noted, data for this article were either provided by native speakers of Thai, were obtained via queries to the SEAlang Library Thai Text Corpus (developed by the Center for Research in Computational Linguistics in association with the University of Wisconsin Center for Southeast Asian Studies and accessible free of charge at http://sealang.net/thai/corpus.htm), or were modeled by my consultants from data so obtained. Thai transcription herein follows Haas 1964, with the exceptions that (i) syllable-final stops, transcribed by Haas as always voiced, are here transcribed as voiceless (reflecting their normal phonetic rather than putatively phonological value) and (ii) Haas' $y$ is written as IPA $i$.

Abbreviations: $1 / 3$ 1st/3rd person; A transitive subject; ACHV achievement; ACOP attributive copula; ADJ adjective; ADV adverb(ial); ADVP adverbial phrase; ANZR active nominalizer; AVZR adverbializer; AZR adjectivalizer; CLF classifier; COMP comparative; COMT comitative; CTZR complementizer; DISJ disjunction; DST distal demonstrative; EXC excessive; EXCL exclamation; GEN genitive; 
GENR generic; H head; HEST hesitation; IPF inchoative perfect; IRR irrealis; LNK linker; MOD modifier; N noun; NEG negator; NHUM non-human; NP noun phrase; o transitive object; PFV perfective; PFX prefix; POT potential; PQ polar question; PRED predicate (phrase); PRX proximate demonstrative; RDUP reduplication; REL relativizer; s intransitive subject; SFOC sequential focus; SNZR stative nominalizer; v verb.

\section{References}

Aikhenvald, Alexandra Y. 2007. Typological distinctions in word-formation. In Timothy Shopen (ed.), Language typology and syntactic description (2nd edition), Vol. 3: Grammatical categories and the lexicon, 1-65. Cambridge: Cambridge University Press.

Baker, Mark. 2003. Lexical categories: Verbs, nouns, and adjectives. Cambridge: Cambridge University Press.

Bhat, D. N. S. \& Regina Pustet. 2000. Adjective. In Booij et al. (eds.) 2000, 757-770.

Booij, Geert, Christian Lehmann \& Joachim Mugdan (eds.). 2000. Morphology: An international handbook on word-formation. Berlin: Mouton de Gruyter.

Chafe, Wallace. 1980. The Pear Stories: Cognitive, cultural, and linguistic aspects of narrative production. Norwood, NJ: Ablex.

Croft, William. 1991. Syntactic categories and grammatical relations. Chicago: University of Chicago Press.

Croft, William. 2001. Radical Construction Grammar. Oxford: Oxford University Press.

Croft, William. 2005. Word classes, parts of speech and syntactic argumentation. Linguistic Typology $9.431-441$.

DeLancey, Scott. 1986. Toward a history of Tai classifier systems. In Colette Craig (ed.), Noun classes and categorization, 437-452. Amsterdam: Benjamins.

DeLancey, Scott. 2001. Functional Syntax. Lecture series presented at the Linguistic Society of America Summer Linguistics Institute, University of California at Santa Barbara, Summer 2001.

Diller, Anthony. 1980. Cross-cultural pain semantics. Pain 9. 9-26.

Dixon, R. M. W. 1977. Where have all the adjectives gone? Studies in Language 1. 19-80.

Dixon, R. M. W. 2000. A typology of causatives: Form, syntax and meaning. In R. M. W. Dixon \& Alexandra Y. Aikhenvald (eds.), Changing valency: Case studies in transitivity, 30-83. Cambridge: Cambridge University Press.

Dixon, R. M. W. 2004. Adjective classes in typological perspective. In Dixon \& Aikhenvald (eds.) 2004, 1-49.

Dixon, R. M. W. \& Alexandra Y. Aikhenvald (eds.). 2004. Adjective classes: A cross-linguistic typology. Oxford: Oxford University Press.

Enfield, N. J. 2004. Adjectives in Lao. In Dixon \& Aikhenvald (eds.) 2004, 323-347.

Enfield, N. J. 2007. A grammar of Lao. Berlin: Mouton de Gruyter.

Evans, Nicholas. 2000. Word classes in the world's languages. In Booij et al. (eds.) 2000, 708-732.

Evans, Nicholas \& Toshiki Osada. 2005. Mundari: The myth of a language without word classes. Linguistic Typology 9. 351-390.

Givón, Talmy. 1984. Syntax: An introduction. Vol. 1. Amsterdam: Benjamins.

Haas, Mary. 1964. Thai-English student's dictionary. Stanford, CA: Stanford University Press.

Hajek, John. 2004. Adjective classes: What can we conclude? In Dixon \& Aikhenvald (eds.) 2004, 348-261.

Hengeveld, Kees. 1992. Non-verbal predication: Theory, typology, diachrony. Berlin: Mouton de Gruyter.

Hundius, Harald \& Ulrike Kölver. 1983. Syntax and semantics of numeral classifiers in Thai. Studies in Language 7. 165-214.

Iwasaki, Shoichi. 2002. Proprioceptive-state expressions in Thai. Studies in Language 26. 33-66. 
Iwasaki, Shoichi \& Preeya Ingkaphirom. 2005. A reference grammar of Thai. Cambridge: Cambridge University Press.

Jespersen, Otto. 1924. The philosophy of grammar. London: Allen \& Unwin.

Kuno, Susumu \& Preya Wongkhomthong. 1981. Relative clauses in Thai. Studies in Language 5. 195-226.

Langacker, Ronald W. 1987. Nouns and verbs. Language 63. 53-94.

Matisoff, James A. 1973. The grammar of Lahu. Berkeley, CA: University of California Press.

Matisoff, James A. 1986. Hearts and minds in South-East Asian languages and English: An essay in the comparative lexical semantics of psycho-collocations. Cahiers de Linguistique - Asie Orientale 15. 5-57.

McCawley, James D. 1992. Justifying part-of-speech assignments in Mandarin Chinese. Journal of Chinese Linguistics 20. 211-246.

Naumann, Bernd \& Petra M. Vogel. 2000. Derivation. In Booij et al. (eds.) 2000, 929-943.

Newmeyer, Frederick. 2007. Linguistic typology requires crosslinguistic formal categories. Linguistic Typology 11. 133-158.

Prasithrathsint, Amara. 2000. Adjectives as verbs in Thai. Linguistic Typology 4. 251-271.

Schachter, Paul. 1985. Parts-of-speech systems. In Timothy Shopen (ed.) Language typology and syntactic description, Vol. 1: Clause structure, 3-61. Cambridge: Cambridge University Press.

Sookgasem, Prapa. 1996. The predicative-adjective construction in Thai. In Pan-Asiatic Linguistics: Proceedings of the Fourth International Symposium on Languages and Linguistics, Bangkok, July 8-10, 1996. Bangkok: Institute of Language and Culture for Rural Development, Mahidol University at Salaya.

Stassen, Leon. 1997. Intransitive predication. Oxford: Clarendon.

Thompson, Laurence C. 1991. A Vietnamese reference grammar (revised edition). Honolulu: University of Hawai'i Press.

Thompson, Sandra A. 1991. A discourse approach to the cross-linguistic category "adjective". In John A. Hawkins (ed.), Explaining language universals, 167-185. Oxford: Blackwell. 